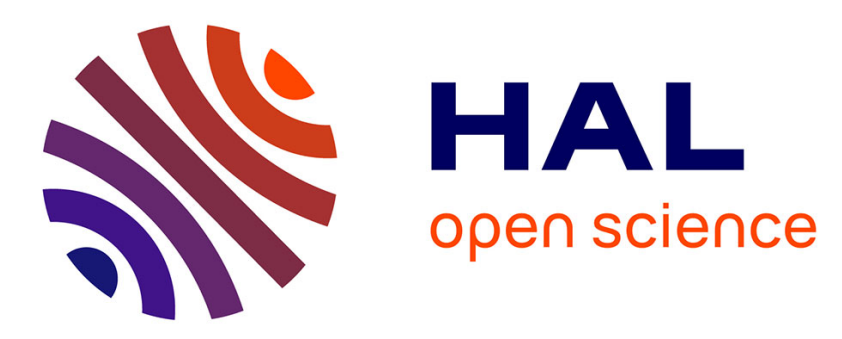

\title{
An Experiment in the Economic Consequences of Additional Disclosure: The Case of the Fair Value of Unlisted Equity Investments
}

Yuan Ding, Thomas Jeanjean, Cédric Lesage, Hervé Stolowy

\section{- To cite this version:}

Yuan Ding, Thomas Jeanjean, Cédric Lesage, Hervé Stolowy. An Experiment in the Economic Consequences of Additional Disclosure: The Case of the Fair Value of Unlisted Equity Investments. La place de la dimension européenne dans la Comptabilité Contrôle Audit, May 2009, Strasbourg, France. pp.CD ROM. halshs-00458950

\section{HAL Id: halshs-00458950 \\ https://shs.hal.science/halshs-00458950}

Submitted on 6 Mar 2010

HAL is a multi-disciplinary open access archive for the deposit and dissemination of scientific research documents, whether they are published or not. The documents may come from teaching and research institutions in France or abroad, or from public or private research centers.
L'archive ouverte pluridisciplinaire HAL, est destinée au dépôt et à la diffusion de documents scientifiques de niveau recherche, publiés ou non, émanant des établissements d'enseignement et de recherche français ou étrangers, des laboratoires publics ou privés. 


\title{
An Experiment in the Economic Consequences of Additional Disclosure: \\ The Case of the Fair Value of Unlisted Equity Investments
}

\author{
Yuan Ding \\ China-Europe International Business School (CEIBS)
}

Thomas Jeanjean

HEC Paris

Cédric Lesage

HEC Paris

Hervé Stolowy

HEC Paris

This draft - March 12, 2009 - Please do not cite or circulate without permission - Comments welcome

Thomas Jeanjean, Cédric Lesage and Hervé Stolowy acknowledge the financial support of the Europlace Institute of Finance and the INTACCT programme (European Union, Contract No. MRTN-CT-2006-035850). They are members of the GREGHEC, CNRS Unit, UMR 2959. Yuan Ding acknowledges support from the CEIBS Research Funding. The authors are grateful to Antoine Bracchi, Vedran Capkun (discussant), Jérôme Chevy, Christophe Marion, Bruno Oxibar (discussant) and participants at the Europlace Institute of Finance Annual Forum (December 2008), HEC Accounting and Management Control Department Research Seminar (December 2008), Amsterdam Business School Accounting Section Seminar (February 2009) and IAS/AAA Mid-year meeting (February 2009) for helpful comments. The authors are also indebted to Ann Gallon for her much appreciated editorial help. They thank Julie Coutton, Sophie Marmousez and Olivier Xu for their able research assistance. Responsibility for any remaining errors rests fully with the authors. 


\title{
An Experiment in the Economic Consequences of Additional Disclosure: \\ The Case of the Fair Value of Unlisted Equity Investments
}

\begin{abstract}
We investigate the economic consequences of additional disclosure about assets with no active market in terms of liquidity, perception of information reliability and relevance. We use an experimental design: 181 MBA students are asked to value 24 investments. We manipulate the level of disclosure on the fair value of assets (Limited versus Full), the perception of expected profit (Gain versus Loss) and the firm's business risk (Low versus High). In the case of Limited (resp. Full) disclosure, participants are given a point estimate for the fair value of the investment (resp. plus a range of possible fair values). We find that in the Full disclosure situation, participants tend to make an offer more frequently, to bid prices lower than the fair value and to earn a lower return on their investments compared to the Limited disclosure case. These consequences vary with the environment (expected profit and risk).
\end{abstract}

Keywords: fair value; fair value measurement; disclosure; relevance; reliability; risk; SFAS 157; IFRS 7 


\section{INTRODUCTION}

The usefulness and accuracy of fair value measurement (FVM) has been widely and hotly debated. From an academic point of view, the evidence is mixed. There is an extensive body of literature on the relevance of fair value accounting and fair value disclosure (Barth 1994; Barth and Landsman 1995; Barth et al. 1996; Eccher et al. 1996; Park et al. 1999; Barlev and Haddad 2003; Landsman 2007). But not all findings are in favor of unrestricted use of fair value. For example, using the British real estate and investment fund industries as experimental settings where historic cost and fair value accounting can be compared, Danbolt and Rees (2008) find that fair values are highly relevant and largely unbiased where values are unambiguous. Where values are subject to uncertainty, however, which will normally be the case, value relevance will be lower and biased accounting may occur. In other words, the relevance of FVMs depends on their reliability. In the same vein, Plantin et al. (2008) show that the trade-offs between historical cost and fair value are far from one-sided. While the historical cost regime has some inherent inefficiency, marking-to-market can involve other types of inefficiencies by injecting an artificial risk that erodes the information value of prices and induces suboptimal real decisions. They construct a framework to weigh the pros and cons, and find that the damage done by marking-to-market is greatest when claims are (1) long-lived, (2) illiquid, and (3) senior.

Standard-setters are aware of the weaknesses of the fair value approach when no active, liquid market exists. This is why SFAS 157 (FASB 2006) distinguishes three levels of fair value classified by reliability, according to the inputs needed to compute it. Level 1 corresponds to the most reliable valuation and level 3 to the least reliable. Level 1 fair value is based on the inputs of listed prices for assets (or liabilities) that are identical to the object of the valuation, on an active market. Level 2 fair value is derived from listed prices on an active market for similar assets, or listed prices for identical assets on an inactive market. Level 3 fair value is adopted when there is no or hardly any observable market data available. Use of information sources not observable on the market is possible, but must reflect the entity's judgment as to the expectations of market participants. The management must make assumptions about market actors' assumptions. For example, to value an unlisted investment for which there are no comparable firms, it is possible to use the discounted future cash flows anticipated by the firm. Given the difficulty of level 3 valuations, fair value measurement must keep use of non-observable data to a minimum. 
Level 3 fair value valuations have attracted most of the criticism leveled at fair value reporting (see, e.g., Benston 2008). For instance, Hitz (2007, 324) observes that “opponents of fair value measurement (...) criticize the questionable reliability of fair value measures, especially for model-based estimates relying on management's expectations and projections" (emphasis added). As Maines and Wahlen (2006, 399) state, "reliability is an essential characteristic for accounting information to be useful for decision making.”

In this paper, we investigate the economic consequences of additional disclosure about assets with no active market (Level 3 fair value measurements). IFRS 7 (IASB 2005) requires the disclosure of sensitivity tests for assets with no active market. Such is not the case with the American standard SFAS 157 (FASB 2006) that does not require sensitivity tests but prescribes a certain degree of disclosure. In practice, as our exploratory study of the annual reports of the 10 U.S. and 10 U.K. leading private equity firms shows, firms hardly ever publish additional information on FVMs.

As additional information is rarely published, empirical research on actual firm data is not possible. We decided to use an experimental approach to assess the consequences of disclosing or not disclosing ranges of fair values. ${ }^{1} 181$ MBA students participate as fictitious investors. Each participant is asked to evaluate a potential investment and to state whether she is willing to participate in an auction (bidding at the value she has just decided) given a set of information on the fair value of the firm's assets. Each participant is asked to participate in 24 rounds. For each round, we manipulate either the level of disclosure on the fair value of assets (Limited versus Full disclosure), the expected profit (Gain versus Loss, this variable is labeled Domain, consistent with Einhorn and Hogart (1986)) and the firm's business risk (Low versus High). In the case of Limited disclosure, participants are only given the point estimate of the fair value of the investment. With Full disclosure, they are given the point estimate of the fair value plus a range of possible fair value estimates. We find that when participants are provided with Full disclosure, they tend to make an offer more frequently and to deviate more importantly from the fair value. They also earn a lower return on their investments compared to the case where they are provided with Limited disclosure.

From an empirical point of view, this paper makes three contributions. First, we find that a full disclosure policy has economic consequences in terms of market liquidity (effective participation in the market), tends to increase the discount attributed by participants to the

\footnotetext{
${ }^{1}$ Experimental markets are used to investigate the emergence of a disclosure equilibrium because of the difficulty of collecting the necessary data to investigate this issue (for instance the information sets of managers, investors and competing firms) from naturally occurring markets (King and Wallin 1995, 141).
} 
Disclosed Fair Value and lowers their ability to generate returns. Second, these effects vary in magnitude depending on the business environment (domain and risk level). Finally, the economic consequences of a Full disclosure policy compared to a Limited disclosure policy tend to be mixed (more market participation, perception of lower information reliability, and lower returns). In other words, we do not find support for the IASB perspective approach on disclosure.

The rest of the paper is organized as follows. In the next section, we provide some background on fair value reporting of unlisted equity investments. We then present the theoretical framework that can explain the effect of increased disclosure on decision-making. The fourth and fifth sections describe our laboratory experiment, followed by our empirical findings. Section six reports supplementary analyses and a discussion in section seven concludes the paper.

\section{FAIR VALUE REPORTING OF UNLISTED EQUITY INVESTMENTS}

The regulations on fair value can be analyzed in terms of reporting, measurement and disclosure. While Appendix 1 presents the first two aspects (reporting and measurement of fair value), we concentrate on disclosure because additional disclosure is presented as one solution to the considerable and vivid debate on the usefulness and on the accuracy of FVM, especially when there is no active market (Level 3 fair value measurements).

In the case of no active market, FVMs are based on valuation models and are subject to high uncertainty. They represent an opinion about the value of the asset and rely on complex models (e.g., DCF, comparables). They are based on assumptions that are not necessarily explicit and which could justify the role of additional disclosure.

\section{Disclosure and Sensitivity Analysis}

Before the implementation of SFAS 157 (FASB 2006), few current accounting regulations that require FVM also required disclosures about those measurements. To improve transparency in financial reporting, the FASB decided to require expanded disclosures on FVMs using significant unobservable inputs and the effects of such measurements on earnings (FASB 2006, para. C17).

More precisely, for assets reported at fair value on a recurring basis in periods subsequent to initial recognition, the reporting entity must disclose information that enables users of its financial statements to assess the inputs used to develop those measurements; and for recurring FVMs using significant unobservable inputs (level 3), the effect of those 
measurements on earnings (or changes in net assets) for the period must also be disclosed (FASB 2006, para. 32).

However, in the Exposure Draft the Board expressed its view that standardizing such disclosures for all assets measured at fair value (for example, requiring disclosure of the assumptions used in fair value valuation) would not be practical. The Board noted that in some cases, an overwhelming volume of information would need to be disclosed to be meaningful. Because sensitivity disclosures rely largely on those assumptions, the Board also decided not to require sensitivity disclosures. Instead, the Statement establishes broad disclosure objectives, which the Board expects to consider as a basis for requiring more specific disclosures in individual accounting pronouncements that require FVMs on a projectby-project basis (FASB 2006, para. C101).

Internationally, IFRS 7 (IASB 2005, para. 27) states that "an entity shall disclose: (a) the methods and, when a valuation technique is used, the assumptions applied in determining fair values of each class of financial assets (...). (c) for fair values that are recognized in the financial statements, if changing one or more of those assumptions to reasonably possible alternative assumptions would change fair value significantly, the entity shall state this fact and disclose the effect of those changes. For this purpose, significance shall be judged with respect to profit or loss, and total assets or total liabilities, or, when changes in fair value are recognized in equity, total equity. (d) if (c) applies, the total amount of the change in fair value estimated using such a valuation technique that was recognized in profit or loss during the period." ${ }^{2}$ IFRS 7 refers explicitly to sensitivity analysis: "To provide users of financial statements with a sense of the potential variability of fair value estimates, the Board decided that information about the use of valuation techniques should be disclosed, in particular the sensitivities of fair value estimates to the main valuation assumptions” (IASB 2005, para. BC38). ${ }^{3}$

A group of experts appointed by the IASB (IASB Expert Advisory Panel 2008, 35) emphasizes the usefulness of sensitivity disclosure: "the estimation of the fair value of the instrument could fall within a range of values depending on the selection of inputs or the model used, and the choice of inputs and models might involve significant judgment. For

\footnotetext{
${ }^{2}$ These requirements were added to IAS 32 in 2003 (IASB 2003a, para. 92), and later transferred to IFRS 7 (IASB 2005).

${ }^{3}$ As an exception to this rule, disclosures of fair value are not required when investments in equity instruments are measured at cost, which is the case when the fair value cannot be measured reliably (IASB 2005, para. 29). As stated in Appendix 1, and as will be seen later from our survey of annual reports, this exception is rarely applied in practice, and investments in equity instruments are usually reported at fair value.
} 
example, the valuation could be sensitive to a particular input that might not be observable and users might want a quantification of this sensitivity. Transparent disclosure of the judgments made helps users understand the significance of the judgments." In short, the FASB has decided not to explicitly require sensitivity disclosures, whereas the IASB has decided to require publication of a sensitivity analysis where necessary.

\section{Disclosure Practices: Annual Report Survey}

We chose the two largest capital markets ${ }^{4}$ in the world, the U.S. and the U.K., to study the disclosure practices of private equity companies. On an exploratory basis, we used the Infinancials database ${ }^{5}$ to select a sample of 10 companies from each country. ${ }^{6}$ Table 1 provides a disclosure analysis of the annual (or 10-K) reports of these companies for the year 2007.

\section{Insert Table 1 About Here}

Several common features are visible from this table:

- All companies state their unlisted investments at fair value.

- Almost all companies refer to the use of valuation techniques, the exceptions being explained by the small proportion of unlisted companies in the total portfolio. Companies often refer to valuation "determined in good faith by [the] Board of Directors." Concerning the valuation techniques, American Capital is a representative example. This company explains that "the methodologies consist of valuation estimates based on: valuations of comparable public companies, recent sales of comparable companies, discounting the forecasted cash flows of the portfolio company, the liquidation or collateral value of the portfolio company's assets, third party valuations of the portfolio company, third party sale offers to buy, potential strategic buyer analysis and the value of recent investments in the equity securities of the portfolio company.”

- While all the companies, apart from a few British companies, report the cost and the fair value of each investment (or of major investments) separately, they almost never disclose

\footnotetext{
${ }^{4}$ Source: http://www.reuters.com/article/businessNews/idUSL2224181520070623.

${ }^{5}$ Available at www.infinancials.com. We chose this database because it contains an extensive library of annual reports available in PDF format.

${ }^{6}$ We drew the selection from the ICB "Equity investment instruments" Sector, adding "private equity" in the key words. At the time of the extraction, we retrieved 19 U.S. companies and 21 U.K. companies. We selected the 10 largest companies (sorted by total assets). All annual reports were available either from the Infinancials database or the company's website. We searched for the terms "range", "sensitivity", "tests", "valuation of investments", "valuation of portfolio investments" and "valuation of portfolio securities". In addition, for the fullest coverage of information, we read the entire text of the annual reports.
} 
the valuation technique associated with each (or each major) investment, again with the exception of a few British companies.

- In almost all the annual reports studied, there is no reference to sensitivity tests concerning the determination of the fair value of investments. ${ }^{7}$ One interesting exception is a British company, SVG Capital, which discloses the following information: "A sensitivity analysis has been performed on the valuations of the 20 largest underlying investee companies, which had an aggregate valuation (before providing for carried interest) of $£ 1,157.0$ million or $85.0 \%$ of the gross private equity portfolio valuation (...), the results of which are set out in the table below":

\begin{tabular}{|l|c|c|c|}
\hline & $\begin{array}{c}\text { Fair value } \\
£ \text { millions }\end{array}$ & $\begin{array}{c}\text { Hypothetical fair } \\
\text { value } \\
(10 \% \text { uplift }) \\
£ \text { millions }\end{array}$ & $\begin{array}{c}\text { Hypothetical fair } \\
\text { value } \\
\text { (10\% write-down) } \\
£ \text { millions }\end{array}$ \\
\hline 31 December 2007 & & & 936.8 \\
\hline $\begin{array}{l}\text { Gross valuation of 20 largest investee } \\
\text { companies }\end{array}$ & $1,157.0$ & $1,370.2$ & -19.0 \\
\hline Change in valuation/effect on income & & $+18.4 \%$ & \\
\hline
\end{tabular}

- With the exception of the above-mentioned company, the sampled companies never publish a range of values.

In summary, from this exploratory study, we can conclude that companies do not publish any sensitivity analysis, which rules out any empirical study based on sensitivity figures. This explains the usefulness of a laboratory experiment to investigate the consequences of additional disclosure on FVMs.

Our survey of disclosure practices is consistent which Michaels (2004) who points out that the SEC "has told companies repeatedly that annual reports need more details on the estimates and assumptions behind the numbers.” An SEC executive even added that the SEC wanted companies to "lay out what would happen under certain future scenarios”, which this executive called a “sensitivity analysis” (Michaels 2004).

\section{THEORETICAL FRAMEWORK AND HYPOTHESIS DEVELOPMENT}

In this paper, we examine how investors react to additional disclosure on fair values. Modeled fair value is by nature uncertain as it aggregates a distribution of probabilities in one single point estimate. Disclosing a range of fair values is similar to providing information on this distribution.

\footnotetext{
${ }^{7} \mathrm{~A}$ few companies mention the "interest rate sensitivity", i.e. the change in earnings that may result from changes in the level of interest rates.
} 


\section{Modeled fair value: a type of "vague" information}

Financial statements and the terms and rules used in accounting are affected to varying degrees by the uncertainty of the information disclosed (March 1987). Godfrey et al. (2003, 19) recall that "even numbers that many regards as 'objective' and 'verifiable' are mere abstractions of a financial world that is complex, unsystematic and imprecise.” The concept of "vague information" encompasses two distinct types of imprecision-about the potential outcomes and about their underlying probabilities (Du and Budescu 2005, 1791). For instance, the widely used term ambiguity refers to imprecisely specified probabilities (Ellsberg 1961). As Godfrey et al. $(2003,82)$ put it, "the problem of vagueness of the attribute is not uncommon in accounting." For example, in accounting practices, vague information can be found in the "risk disclosures", like sensitivity tests, VaRs (Value at Risk) ranges (Hodder et al. 2001), and also in accounting estimates, like a modeled fair value, which is by nature vague, as it aggregates a distribution of probabilities in one single point estimate.

\section{Investment behavior and vagueness avoidance}

Previous literature shows that when investors are confronted with vague information, they tend to adopt a “vagueness avoidance” behavior (Du and Budescu 2005). Ellsberg (1961) illustrated this notion: in a lottery setting, people overwhelmingly favour a lottery with known probabilities and will even pay to avoid the ambiguous lottery (e.g., Ellsberg 1961; Curley et al. 1986) even though a normative model of decision making would prescribe indifference between the lotteries (Camerer and Weber 1992). Vagueness avoidance has been invoked to explain anomalies and irregularities in investment behavior (Mukerji and Tallon 2001; Chen and Epstein 2002). It has been documented in individual settings (Einhorn and Hogarth 1986), laboratory settings (Sarin and Weber 1993), and field settings (Hogarth and Kunreuther 1989).

\section{Disclosure about a vague information and investors' behavior}

In this paper, we examine how investors react to additional disclosure on fair values. With regard to sensitivity disclosure, the position of the above-mentioned group of experts appointed by the IASB (IASB Expert Advisory Panel 2008, 35) is consistent with the idea that modeled fair value is vague by nature and this vagueness should be reduced by disclosing additional information on the level of vagueness (like for instance a range of possible fair values, or a sensitivity test).

However what could be the investors' behavior? Do they perceive the additional disclosure of the range of fair values as a reducer of vagueness, as the standard-setters do? In 
this case, the range of fair values can be interpreted as presenting the "limits" to the vagueness of the fair value figure. Alternatively, do investors view additional disclosure as an amplifier of vagueness because it emphasizes the imprecision of the fair value estimate?

Empirical results mentioned above let this question open, as they all rely on a vague/non vague information comparison. For example, Du and Budescu (2005) compare a point versus confidence interval and Hirst et al. (1999) study the form of a forecast (point or range forecasts). In the context of environmental liabilities, Kennedy et al. (1998) investigate the impact of the disclosure of a best estimate, a range, the minimum or the maximum. Conversely, our paper differs from previous settings in the sense that participants do not have the choice between two measures with different levels of vagueness. Participants are provided either with vague information (the fair value estimate) or with this vague information plus information on the level of vagueness (i.e., point estimate plus range of values). Therefore, how this information affects investors' decisions and performance is an open issue. To address it, we concentrate on three economic consequences of additional disclosure: market liquidity, perception of information reliability and information relevance.

\section{Market liquidity}

From an economic point of view, increased disclosure is associated with lower information asymmetry and greater willingness to invest (Akerlof 1970; Diamond and Verrecchia 1991). Empirical literature generally supports this view. Bushee and Leuz (2005) document that in the case of a regulatory change mandating OTCBB firms to comply with reporting requirements under the 1934 Securities Exchange Act, firms previously filing in compliance with the SEC disclosure requirements experience positive stock returns and permanent increases in liquidity, suggesting positive externalities from disclosure regulations. Bailey et al. (2006), find that volume reactions to earnings announcements typically increase significantly once a company cross-lists in the U.S., and this change is related to the level of disclosure.

Information also increases confidence in judgments (Gill et al. 1998; Hall et al. 2007). As investors estimate the parameters needed to make their decision based on available information, their confidence level depends on the attributes of their information set (Botosan 2006, 33). Heath and Tversky (1991) have shown that people prefer to bet on events about which they have some expertise than on random chance events or on events they feel ignorant about. 
Both theories are consistent with the idea that high levels of disclosure are more likely to attract investors and thereby increase liquidity of the firm's stock. Therefore we state our first hypothesis:

H1: Additional disclosure is positively associated with market liquidity.

\section{Perception of reliability of accounting numbers}

We postulate that the closer to the point estimate of the fair value the participants bid, the higher the perceived reliability of accounting numbers. The effect of disclosing a range of fair values (in addition to a point estimate) on the perceived reliability of accounting numbers is uncertain.

On the one hand, an investment decision is by nature complex. In this situation, individuals provided by too much information tend to reach information overload (Schick et al. 1990) and as recalled by Kennedy et al. (1998), decision makers faced with uncertainty tend to use fairly simple but generally functional heuristics and decision rules. Additional information is not always incorporated into the decision process. Tversky and Kahneman (1982) propose an anchoring and adjustment heuristic. With this heuristic, individuals make estimates by starting from an initial known value (e.g., the point estimate) that is adjusted to yield the final estimate, that is biased toward (anchored by) the initial value. Research in psychology predicts that point estimate will be seen as more precise than range of values (Hirst et al. 1999). This is why we expect an investor provided with full information to offer a bid price close to the point estimate.

On the other hand, providing a range makes salient both higher and lower possible values, whereas a point estimate provides only one anchor value (Highhouse 1994). This is why we expect investors to give more weight to their beliefs and/or other information to deviate from the point estimate when provided with full information. Moreover, previous studies consistently demonstrate that when investors face vagueness, they tend to require a higher premium to compensate for the additional uncertainty (Mukerji and Tallon 2001; Chen and Epstein 2002).

Given the conflicting expectations provided by our theoretical framework (anchoring vs. uncertainty effect), we state our second hypothesis in a non-directional form:

H2: Additional disclosure is associated with the perception of information reliability. 


\section{Return}

We postulate that information is relevant if it enables participants to earn a positive return. The effect of disclosing a range of fair values (in addition to a point estimate) on the ability of participants to earn positive returns is uncertain. On the one hand, a maximum amount of information is necessary for good investment decisions. When a firm commits to increased levels of disclosure, the potential for information asymmetries to arise between the management of the firm and its shareholders or among buyers and sellers of the firm's shares diminishes (Bailey et al. 2006, 176). Informative disclosure provides an opportunity for a decision-maker to obtain an incremental improvement in assessing the real prospects for an enterprise. Nonowner investors benefit from the lower information risk of making an error in allocating their resources (Elliott and Jacobson 1994).

On the other hand, Huber et al. (2008) show that having more information than others does not always lead to higher returns when trading on financial markets. Hall et al. (2007) provide explanations for this potential underperformance. First, more information often increases confidence in judgment even if the accuracy of judgment is not affected. Second, additional information may render other information less salient and ultimately decrease the accuracy of predictions. Altogether, these two effects create an "illusion of knowledge" that leads to poorer decisions.

Given these conflicting predictions, we state our third hypothesis in a non-directional form:

H3: Additional disclosure is associated with information relevance.

\section{Interaction with the characteristics of the environment}

These three hypotheses illustrate the economic consequences of additional disclosure. However, uncertainty impacts the decision maker's behavior (Kahneman et al. 1982). Decision makers tend to use heuristics to simplify the judgment task, which could be hindered by biases (Hogarth and Makridakis 1981; Einhorn and Hogarth 1986) and limitations in their information processing capacities (Miller 1956; Schroder et al. 1967; Newell and Simon 1972). Consequently, many have presumed that an explicit disclosure of the information uncertainty should aid decision-making. In their analysis of previous experimental research on the usefulness of the disclosure of confidence intervals, Foong et al. (2003) show that probabilistic information disclosure enhanced decision performance as it helps decreasing task complexity. 
Professional regulatory bodies advocate for additional disclosures in the case of complex decision making processes. Such additional disclosure mentioned above concerning the group of experts appointed by the IASB (IASB Expert Advisory Panel 2008) is expected to mitigate task complexity, because the decision accuracy of heuristics tends to decrease as task complexity increases (Thorngate 1980; Johnson and Payne 1985).

Moreover, many empirical results have demonstrated that one main determinant of attitude towards vagueness is the perceived loss/gain outcomes (Einhorn and Hogarth 1986). For instance, Du and Budescu (2005) show that, when investors face investment options with vague information, they exhibit a stronger concern for vagueness in the domain of gains than in the domain of losses, and they can be indifferent or vagueness seeking in the domain of losses, which is consistent with previous findings (Einhorn and Hogarth 1985; Camerer and Weber 1992; Budescu et al. 2002).

Given that we form no expectation on whether or not information on the range of possible value in addition to a point estimate increases or decreases the level of vagueness, we posit a non directional hypothesis:

H4a: Economic consequences of additional disclosure interact with the domain.

As recalled by Du and Budescu (2005), prior research has found that individual attitudes toward risk and toward vagueness are not closely associated and that attitude toward vagueness is an important, distinct, and independent factor in decision behavior (Chen and Epstein 2002). Consequently, we also allow the level of risk to vary in our experimental design. We state a non directional hypothesis:

H4b: Economic consequences of additional disclosure interact with the riskiness of the environment.

In the next section, we will test these hypotheses on information disclosed on fair value.

\section{EXPERIMENTAL METHOD}

In this paper, the aim of our experiment is to examine the effect of additional information on fair values (publication of a range of fair values in addition to a point estimate of the asset's fair value) on investors' decisions to purchase securities and their consequences.

\section{Organization of the Experiment}

Each experimental session consists of a series of 24 single-period call auctions (called "rounds"). Participants (the "investors" or "subjects") are asked to invest in 24 unlisted companies. During each round, the subjects have the opportunity to buy one and only one 
"share" for cash, in a written single call auction. ${ }^{8}$ At each round, they can choose whether or not to participate in the call auction.

For each auction, we manipulate three variables: Disclosure, Domain and Risk. Disclosure can be either "Limited Disclosure" (disclosure of a point estimate corresponding to a single fair value) or "Full Disclosure" (disclosure of the point estimate fair value and the minimum-maximum range). Note that the point estimate (also called the "single estimate") is the best estimate of the fair value of the asset, and it corresponds to the accounting value of the asset under both IASB and FASB regulations (see Appendix 1 for details). As in Du and Budescu (2005), all decisions in the experiment are set in a context where the options are naturally framed as potential gains or potential losses through simple comparisons with an implicit benchmark ( $\$ 1,000$ per share - see Appendix 2). The domain is a gain (loss) if the difference between this benchmark and the point estimate of fair value is positive (negative). Note that the benchmark is explicitly disclosed to participants before each auction. Risk is overall business risk assessment and is explicitly disclosed to participant. The Risk variable can take two values: "Low Risk” or "High Risk". The explicit disclosure of the risk level is also supported by other elements given to participants: for instance, "Low Risk" firms distribute dividends whereas "High risk" do not. In the same vein, "Low Risk" firms tend to operate in "brick and mortar" industries, whereas "High Risk" firms operate in new technology.

The variable of interest is Disclosure as we measure the economic consequences of Disclosure (Limited versus Full) when the domain of the decisions (gains and losses) and the business conditions (captured by Risk) vary.

Each participant experiences all 24 scenarios. $^{9}$ The 24 scenarios are organized in 12 pairs of scenarios that are fully comparable in terms of Domain and Risk but differ in terms of Disclosure. This means that the same description (business description, salient facts and income) will occur twice, once for the Limited disclosure scenario and once for the Full disclosure scenario. The two scenarios will be referred to as a pair (see an example in Appendix 3). Hence, we have a 2 (cases of disclosure) x 2 (domains) x 2 (categories of Risk) within-subjects experimental design. ${ }^{10}$ Each participant experiences 3 times each of the 8

\footnotetext{
${ }^{8}$ The single call auction market has already been used in previous experimental studies (Calegari and Fargher 1997, 407-408).

${ }^{9}$ The scenarios were developed using the 2006 actual portfolio of Northern Investors Company Plc., a U.K. listed private equity firm.

10 "Within-subjects (or 'repeated-measures' designs) where subjects provide more than one observation, generally enhance statistical power by allowing control of between-subjects differences” (Libby et al. 2002, 804).
} 
possible combinations, leading to 24 different rounds. The 24 scenarios (12 pairs of scenarios) are proposed in a random order, different for each participant, to control for recency bias.

Consistent with previous research (e.g., Chow et al. 1996), the first seven rounds are used as a learning phase and the last three may contain biases due to opportunistic behavior by subjects in closing the game, which leaves 14 usable rounds. 181 subjects participate to the experiment. Out of the 4,344 possible rounds (181 participants * 24 rounds), only 2,534 rounds are available for the experiment (181* 14 rounds). Since combinations of Disclosure, Domain and Risk are constructed so that the Limited and Full disclosure scenarios can be compared directly, we then have to reconstruct pairs of similar scenario except in terms of Disclosure. We end up with 840 complete pairs, or 1,680 observations. In order to perform a repeated Anova (see later), we average the three decisions taken by the participants on each combination of Disclosure, Domain and Risk. ${ }^{11}$ Because the 1,680 observations do not include three decisions per participant for each of the eight combinations, as we drop 10 rounds out of 24, the resulting sample, after averaging, includes 577 complete pairs, representing 1,154 observations.

\section{Experimental Design}

At the start of the session, a general information questionnaire is distributed on the subject's age, educational qualifications, experience, gender and risk behavior. ${ }^{12}$ Each participant receives the same preliminary information included in Appendix $2^{13}$ and plays 24 rounds. Each round proceeds as shown in Figure 1. For each round, participants are informed that "the value of the company's shares is around $\$ 1,000$ ", so as to create a "benchmark" against which they can assess the expected gain by acquiring the share.

\section{Insert Figure 1 About Here}

1. For each round, a brief description of the firm (Audited financial information and Business environment) is presented (see Appendix 3). We also provide the participant with the point estimate, which is an ex ante valuation of the fair value of the firm (e.g., 995 for Union Food, see Appendix 3, Panel A). The participant has to assess the value of the firm, i.e., evaluate the investment. After reviewing summarized financial information

\footnotetext{
${ }^{11}$ As mentioned above, each participant repeats three times the eight combinations of Disclosure, Domain and Risk.

${ }^{12}$ Investor risk aversion has been proved to influence investment behavior: conservative investors (with greater risk aversion) demand higher risk premiums whereas speculators (with lower risk aversion) accept greater price volatility (Ang and Schwarz 1985). We therefore include the subject's risk aversion as a control variable and find (in untabulated results) that the inclusion of this variable does not qualitatively affect our results.
} 
on the firm, she must post her bid price (the maximum amount of money she is willing to invest to buy the share) (Question 1 - see Appendix 2).

2. The participant is then asked if she wishes to participate in an auction for the share. (Question 2). If she does not participate, the round is over and the total value of her portfolio is unchanged from the previous round.

3. If she participates, market conditions are modeled (see Appendix 4) ${ }^{14}$ and the participant may win or lose the auction if she decides to make a bid. If the participant's bid has an associated probability (calculated based on normal distribution, with mean 1000 and standard deviation 100 or 250 , depending on the level of risk) greater than 0.4 , then she will win the auction.

4. If the offer is accepted, the modeled value (market value) ${ }^{15}$ of the share (see Appendix 4) is disclosed to the participant and a gain or loss is computed as the difference between the market value and the bid price. If higher than the valuation from step 1, the participant makes a gain equal to the market value minus her bid price; if lower than the valuation from step 1 (bid price), the participant makes a loss. If the participant wins the auction, this gain (loss) is added to (subtracted from) her capital (\$24,000 at the beginning of the simulation). If she loses the auction, her capital is not affected (see Figure 1).

5. There are no transaction costs.

\section{Proxies for Economic Consequences}

Our goal is to examine the economic consequences, if any, of Disclosure levels (Limited versus Full) when the domain of the decisions and the business conditions (complexity of the environment captured by Risk) vary. We analyzed in the hypothesis development three economic consequences: liquidity, reliability and relevance.

To measure liquidity, we assess the participant's willingness to make an offer. More precisely, we code the participant's answer to step 2 (“Are you willing or not to make an offer?”). We use a binary variable Offer coded one if the participant is willing to make an offer and zero otherwise. At the aggregate level, if more participants are willing to make an offer (i.e., if the average value of Offer is closer to one), then liquidity increases.

\footnotetext{
${ }^{13}$ As is standard procedure, before administering the final version of the research instrument, we ran a pilot test on a group of potential subjects to validate the design (see Holm and Rikhardsson 2008, 544).

${ }^{14}$ The investments are not listed. The "market" conditions mentioned in the text correspond to the modeling of the result of the single-period call auctions.

${ }^{15}$ This is not a real "market" value in the sense that the investments are not listed. This value corresponds to the value modeled as the result of the call auction process. For the sake of simplicity, we will use the term "market value” in the rest of the paper.
} 
The second economic consequence investigated is the perception of information reliability. We seek to examine whether or not participants rely more on accounting numbers when they are provided with Full disclosure compared to the case when they are just provided with a point estimate. In a way, we examine the reliability of accounting information from a user perspective: we expect that participants will offer bid prices closer to the disclosed fair value as they see higher reliability of this accounting number. To capture their perception of information reliability, we use a variable labeled Deviation from Disclosed Fair Value (Deviation in short). Deviation is computed as the difference between the bid price of the participant from step 1 minus the point estimate of the Disclosed Fair Value (DFV) of the share, scaled by this DFV of the share to allow comparisons. For instance, if a participant proposes a value of 999 whereas the point estimate was 995, Deviation is $0.40 \%$ (=[999995]/995). ${ }^{16}$ Deviation captures how the bid price proposed by the participants deviate from the accounting fair value of the asset. If Deviation is positive (resp. negative), the participant tends to bid over (resp. under) the fair value. Deviation is computed only for rounds for which the participant decided to make an offer.

The last economic consequence is the relevance of additional disclosure. We seek to examine if participants are more able to earn a return when they are provided with Full disclosure. We label Return the variable that measures the return on investment for each round. If participants decided to make an offer (step 2) and if this offer was accepted (step 3), then Return is computed as the difference between the market value of the asset as simulated by our experimental model (step 4$)^{17}$ and the bid price proposed by the participant, scaled by this bid price to allow comparisons. If participants decided not to make an offer (step 2) or if their offer was rejected (step 3), Return is set to zero. Note that Return is defined for all rounds whatever may be the status of the offer (accepted or rejected). Appendix 4 proposes an example of the measurement of Return.

\section{Participants}

The market participants were 181 student volunteers recruited from MBA classes ${ }^{18}$ at two universities (Institution A and Institution B). ${ }^{19}$ Participants are provided with incentives to

\footnotetext{
${ }^{16}$ See Appendices 3 and 4 for a detailed presentation.

${ }^{17}$ This value could be equivalent to the price proposed by another investor one year later.

${ }^{18}$ The study by Elliott et al. (2007) shows that using MBA students as a proxy for nonprofessional investors is a valid methodological choice. In addition, Holm and Rikhardsson (2008) recall that "students are not relevant subjects (surrogates) for all empirical research areas, but for certain tasks involving information processing and decision-making, university students make decisions that approximate those made by the rest of the general population (see Ashton and Kramer 1980; Liyanarachchi and Milne 2005).”
} 
submit accurate privately formulated estimates of the firm's fair value: the top four results (in each institution) will each receive a $\$ 225$ reward. ${ }^{20}$ The investors’ performance is assessed as follows: the sum of their initial endowment plus the gain (loss) from the purchase of the shares equals the total value of their portfolio at the end the period.

\section{Insert Table 2 about here}

As shown in Table 2, which provides some demographic data, on average, participants are 29.55 years old (ages range from 23 to 45 ) and they all have some professional experience. Their backgrounds are diverse but most of them graduated in Business, Economics and/or Science. In addition, before joining their MBA course $67 \%$ had had some formal education in Accounting, 43\% in Financial analysis and 57\% in Corporate finance. Approximately one third of the participants had worked in a finance-related field (accounting, audit, management control, banking or investment banking). Before participating in the experiment, they all attended an accounting course: they are all familiar with the notions of balance sheet, income statement, fair value, market value and book value. These background analyses help reinforce the validity of our study, as Elliott et al. (2007) point out that researchers should give careful consideration to aligning a task's integrative complexity with the appropriate level of MBA student. Their analysis proves that MBA students who have completed their core MBA courses and are enrolled in or have completed a financial statement analysis course are a good proxy for nonprofessional investors in tasks that are relatively low in integrative complexity.

\section{RESULTS}

We present our results according to our three main hypotheses: market liquidity, perception of information reliability and relevance of additional disclosure.

\section{Market liquidity}

Table 3 presents all the tests referring to hypothesis $\mathrm{H} 1$ (positive association between additional disclosure and market liquidity) and hypotheses $\mathrm{H} 4 \mathrm{a}$ and $\mathrm{H} 4 \mathrm{~b}$ as applied in conjunction with $\mathrm{H} 1$ (the effect of Disclosure on Offer varies with the domain of the decisions

\footnotetext{
${ }^{19}$ The names of the institutions involved in the experiment are withheld to maintain anonymity in the blind review process. As a robustness check, we included the institution as an additional factor. Findings are qualitatively similar.

20 "Experiments testing responses to economic theory need to provide performance-contingent incentives in order to induce subjects to possess the incentives assumed by the economic model” (Libby et al. 2002, 803).
} 
and the risk). The dependent variable for these hypotheses is Offer (willingness to make an offer) which constitutes, as explained above, a proxy for market liquidity.

\section{Insert Table 3 about here}

As a first pass on H1, we compare the proportion of offers made by participants in the Full disclosure cases compared to the Limited disclosure cases. Participants make an offer in 93.4\% of the cases when provided with Limited disclosure versus $95.6 \%$ of the cases when provided with Full disclosure. Using a Paired Wilcoxon signed-rank test, we find the difference to be significant $(\mathrm{z}=-2.608, \mathrm{p}<0.01)$. Our sample is based on 577 complete pairs (see Table 3, Panel A). We remind that a "complete pair" of scenarios includes for a given participant $^{21}$, two scenarios with the same domain and the same level of risk. The only difference between the two scenarios is the level of disclosure: Limited in one case and Full in the other. ${ }^{22}$ The use of this technique (paired samples Wilcoxon signed-rank test) allows measuring the impact of Disclosure on Offer all other things being equal. In other words, reporting a range of fair values rather than only a point estimate of the fair value is associated with a higher tendency to make an offer. This result is consistent with H1. As discussed previously, the provision of additional disclosure is more likely to attract investors which feel more confident.

According to H4a and H4b, we expect the influence of disclosure on offer to vary with Domain (Gain versus Loss) and Risk (High versus Low). We use a 3-way factorial Anova model with repeated measures of Disclosure, Domain and Risk to test the significance of these interactions. Panel C reports results of this Anova whereas panel B tabulates the mean (standard deviation) of Offer for each case of information (Limited versus Full), domain (Gain versus Loss) and level of risk (High versus Low).

Panel C reveals that Disclosure and Domain main effects are significant. Consistent with H1 and Panel A, participants make offers more frequently when they are provided with Full disclosure. Consistent with intuition, participants make offers more frequently when their perception of profit is positive (domain $=$ Gain) rather than negative. The interaction term Disclosure $x$ Domain is also significant (see Table 3, Panel C). This means that the different levels of disclosure do not have the same impact on Offer depending on the nature of Domain (Gain or Loss). Panel B reveals that increased disclosure translates into a higher rate of offer

\footnotetext{
${ }^{21}$ We remind that we average the three decisions taken by each participant for each of the eight possible combinations of Disclosure, Domain and Risk.

${ }^{22}$ An example of pair is given in Appendix 3.
} 
(more market participation) in the loss domain, whereas in the gain domain, the rate of offer is fairly constant whatever may be the level of disclosure.

The three way interaction terms between Disclosure $x$ Risk $x$ Domain is insignificant. The effect of disclosure conditional of the expectation of profit (gain or loss) is not affected by the level of risk. This is confirmed by Panel D of Table 3 that tabulates output of a simple Anova of Offer and Disclosure for each combination of Domain (Gain versus Loss) and Risk (Low versus High) (see Panel D). We only find a marginally significant difference between the impact of Limited and Full disclosure on Offer when the domain is a loss and the risk is high (84.9\% vs. 91.1\% [see Panel B], $\mathrm{F}=2.854, \mathrm{p}<0.10)$.

\section{Perception of information reliability}

Table 4 presents all the tests referring to hypothesis H2 (association between additional disclosure and perception of information reliability) and hypothesis $\mathrm{H} 4$ as applied in conjunction with $\mathrm{H} 2$ (interaction with the domain of the decisions and the risk). The dependent variable for these hypotheses is Deviation, as defined earlier in the paper, which constitutes, as explained above, a proxy for the perception of information reliability.

\section{Insert Table 4 about here}

To test H2, we first compare the level of Deviation for pairs of scenarios of Full and Limited disclosure holding constant other factors (Domain and Risk). Our findings are based on a sample of 541 complete pairs (see Table 4, Panel A). This figure is lower than the number of pairs displayed in Table 3, Panel A, because we can only use complete pairs when the participants decided to make an offer. Participants will more deviate from the DFV in the Full disclosure cases compared to the Limited disclosure cases (-3.3\% versus $-2.5 \%)$. According to a Paired Wilcoxon signed-rank test, this difference is significant $(\mathrm{z}=3.511, \mathrm{p}<$ 0.01). In other words, reporting a range of fair values rather than only a point estimate of the fair value is associated with a higher tendency to offer a bid price lower than the Disclosed Fair Value. This result is consistent with the idea that providing a range of values makes more salient negative news, as represented by the lower bound of the range (Highhouse 1994). When provided with full disclosure, participants impose a higher discount on DFV.

As hypothesis $\mathrm{H} 4$ must be tested in conjunction with $\mathrm{H} 2$ (the economic consequence of additional disclosure interact with Domain and Risk), we first present the mean (standard deviation) for Deviation by domain and level of risk (see Panel B). To analyze the Deviation by disclosure level, domain and level of risk, we use a 3-way factorial Anova model with repeated measures of Disclosure, Domain and Risk. Panel C report our findings. 
All three main effects are significant. The level of disclosure influences the Deviation. Panel B reveals that in the full disclosure case, participants tend to underbid more than in the Limited disclosure case. This is consistent with view that additional disclosure "reveals" bad news, leading participants to impose a higher discount on DFV. Consistent with intuition, participants bid price closer from the DFV in the gain domain than in the loss domain. Participants also propose higher prices when risk is higher, consistent with economic theory.

Hypothesis H4 predicts a significant interaction between Disclosure and Domain, and between Disclosure and Risk. All interaction terms but Domain x Risk (that is not however central in our analysis) are significant. (see Table 4, Panel C). This means that the different levels of disclosure do not have the same impact on Deviation depending on the level of Risk (Low or High). In order to further investigate the relationship between Disclosure and Deviation, we run a simple Anova for each combination of Domain (Gain versus Loss) and risk (Low and High) (see Panel D). We find a significant difference between the impact of Limited and Full disclosure on Deviation when the domain is a gain and the risk is low $(-0.5 \%$ vs. $-1.4 \%$ [see Panel $\mathrm{B}$ ], $\mathrm{F}=8.709, \mathrm{p}<0.01$ ) and when the domain is a loss and the risk is high $(-6.8 \%$ vs. $-9.1 \%, \mathrm{~F}=11.632, \mathrm{p}<0.01)$. In other words, Full disclosure induces a more conservative behavior of participants due to vagueness avoidance. Note however that the behavior of investors is asymmetric for high risk and low risk with regards to the domain.

\section{Relevance}

In Table 5, we analyze the effect of Disclosure on the ability of participants to earn a return. The dependent variable for these hypotheses is Return which constitutes, as explained above, a proxy for the relevance of additional disclosure.

\section{Insert Table 5 about here}

To test H3, we first compare the return earned by participants for each level of Disclosure holding constant Risk and Domain. Our sample is based on 577 pairs (see Table 5, Panel A). When participants are provided with the range of fair value estimates, the return is on average $0.30 \%$ lower than when participants are only provided with a point estimate ( $1 \%$ vs. $0.7 \%)$. A paired Wilcoxon signed-rank test, reveals that this difference is significant $(\mathrm{z}=3.000, \mathrm{p}<$ 0.01). In other words, reporting a range of fair values rather than only a point estimate of the fair value is associated with a tendency to earn a lower return. This result is consistent with the findings of Hall et al. (2007) who state that having more information creates an "illusion of knowledge" which leads to poorer decisions. In our setting, this might be explained by two factors. First, participants when provided with Full disclosure tend to offer lower bid prices 
(see findings on H2). As a consequence, their offers tend to be over rejected biasing returns towards zero. Second, when participants are provided with Full disclosure and when their offer is accepted, they tend to have higher bid prices leading to lower returns.

Panel B of Table 5 tabulates the mean (standard deviation) for Return by domain and level of risk. To explore the significance of the interactions between Disclosure, Domain and Risk, we implement use a 3-way factorial Anova model on the sample corresponding to the complete pairs (1,154 observations, see Table 5, Panel C) with repeated measures of Disclosure, Domain and Risk.

Panel C reports our findings. All main effects are significant. Consistent with H3, return varies (negatively) with the level of disclosure. Consistent with expectations, participants earn a higher return when risk is high and when domain is a gain (see Panel B). H4a and H4b predict a significant interaction between Disclosure and Domain and between Disclosure and Risk, and between Disclosure, Domain and Risk. Findings are consistent with all these predictions. This means that the different levels of disclosure do not have the same impact on Return depending on the Domain (Gain versus Loss) and nature of Risk (Low or High).

In order to further investigate the relationship between Disclosure and Return, we run a simple Anova for each combination of Domain (Gain versus Loss) and Risk (Low and High) (see Panel D). Panel D presents the joint effect of disclosure, the domain and the level of risk on the return earned. Interestingly for our analysis, disclosure has an effect only when the domain is a gain and the level of risk is high. In this case, when participants are provided with the range of fair value estimates, the return is on average $0.7 \%$ lower than when participants are only provided with a point estimate $(2.6 \%$ versus $1.4 \%$ [see Panel $\mathrm{B}$ ], $\mathrm{F}=15.273, \mathrm{p}<$ $0.01)$.

\section{SUPPLEMENTARY ANALYSIS}

In this section, we investigate the sensitivity of our findings to one alternative measure of economic consequences: the criterion used to determine if the auction is successful or not (step 3 of each auction). In the current setting, the offer is accepted if the price bid by the participant is superior to a threshold based on a normal distribution and the risk level (see Appendix 4 for details). This mechanism has common features with the one proposed in the Becker-DeGroot-Marshak method (see Becker et al. 1964). Participants do not compete directly between them to win the auction but they play against a statistical distribution (Gaussian law). This setting has the advantage of simplicity. One limit is that we do not incorporate all participants' beliefs to model the acceptance or rejection of each offer. An 
alternative would be to consider that the offer is accepted if the price bid by the participant is superior to median bid price of all participants for the pair of comparable scenarios. In this case, we interpret individual bid prices as a reservation price: at this price participants are indifferent to selling (or buying) one share or receiving their bid price in cash. Therefore the median bid price for each pair of scenarios “clears the market” because, at this price, $50 \%$ of the participants are willing to sell shares and 50\% are willing to buy shares.

We checked the robustness of our findings if we change the acceptance criteria (Is the bid price superior to a modeled value versus to the median bid price?): findings are similar (and not tabulated for the sake of clarity) and reinforce our confidence in the reported results.

\section{DISCUSSION AND CONCLUSION}

The introduction of FVM for assets and liabilities listed on an active market is now commonly accepted. Its extension to unlisted assets (level 3 valuations) is more questionable and has spurred considerable debate (see Nissim and Penman 2008). SFAS 157 suggests that increased disclosure is an answer to the lack of reliability of level 3 fair valuations. This premise is important, as impaired reliability is associated with lower relevance of the measure (see Maines and Wahlen 2006, 399). The goal of our experiment is to challenge this view. We ask 181 MBA students to value a sequence of 24 distinct potential investments. For each investment, we manipulate the level of disclosure on the fair value of assets (Limited versus Full disclosure), the domain of the decisions (gains versus losses) and the firm's business risk (Low versus High). In the case of Limited disclosure, participants are only given the point estimate of the fair value of the investment. With Full disclosure, they are given the point estimate of the fair value plus a range of possible fair value estimates. We find that Full disclosure is associated with a change in (1) investors' market participation, (2) their perception of information reliability and (3) their capacity to earn returns on their investments.

Taken together, these findings make three contributions. First, they suggest that a full disclosure policy has economic consequences in terms of liquidity (effective participation in the market), perception of information reliability, and ability to generate returns. Second, these effects vary in magnitude with the domain of the decision and risk of the business environment. Finally, the economic consequences of a Full disclosure policy compared to a Limited disclosure policy tend to be mixed (more market participation but lower returns). In other words, we do not find support for the economic perspective approach on disclosure that underlies the IASB regulations. 


\section{APPENDIX 1}

\section{Regulation on Fair value and Fair Value Disclosure}

Relevance and reliability are considered by the FASB (1980) and the IASB (see IASC 1989) as two of the primary qualities that make accounting information useful for decisionmaking. Both standard-setting bodies provide a similar definition of these concepts. In the U.S., "relevant accounting information is capable of making a difference in a decision by helping users to form predictions about the outcomes of past, present, and future events or to confirm or correct prior expectations" (FASB 1980, 5). At the international level, "to be useful, information must be relevant to the decision-making needs of users. Information has the quality of relevance when it influences the economic decisions of users by helping them evaluate past, present or future events or confirming, or correcting, their past evaluations” (IASC 1989, para. 26).

However, to be useful, information must also be reliable. In the U.S., "the reliability of a measure rests on the faithfulness with which it represents what it purports to represent, coupled with an assurance for the user that it has that representational quality” (FASB 1980, 5). Internationally, "information has the quality of reliability when it is free from material error and bias and can be depended upon by users to represent faithfully that which it either purports to represent or could reasonably be expected to represent” (IASC 1989, para. 31).

The question of the treatment of unlisted equity securities, and specifically the provision of disclosures, falls directly into the debate on the trade-off between relevance and reliability. U.S. GAAP and IFRS have adopted a similar, but not identical, approach to treating investments in unlisted equity securities. The regulations can be analyzed in terms of reporting, measurement and disclosure.

\section{Reporting: Use of Fair Value}

In the U.S., reporting of investments in unlisted equity securities (also called "investments in closely held companies" or "investments in privately-held companies") is not regulated by SFAS 115 (FASB 1993), which specifically applies to equity securities with "readily determinable fair values.”23 Reporting for this category of investments follows Regulation S$\mathrm{X}$ of the SEC, which requires registered investment companies to value their investments for the purposes of financial statements in conformity with the valuation concepts prescribed in

\footnotetext{
${ }^{23}$ SFAS 115 (FASB 1993, para. 3) provides several examples where the fair value of an equity security is readily determinable. The main example concerns situations where sales prices or bid-and-asked quotations are available.
} 
the 1940 act (Investment Company Act of 1940). ${ }^{24}$ Investments in companies that are not publicly traded are reported at fair value as determined "in good faith by the Board of Directors” (1940 Act, section 2, para. 41). Consequently, a major concept in the U.S. accounting treatment is the "readily determinable" fair value.

At international level ${ }^{25}$, IAS 39 states in the section devoted to financial assets at fair value through profit or loss that "investments in equity instruments that do not have a quoted market price in an active market, and whose fair value cannot be reliably measured (...), shall not be designated as at fair value through profit or loss" (IASB 2003b, para. 9) but "shall be measured at cost” (IASB 2003b, para. 46-c). IAS 39 allows fair value reporting of investments in unlisted equity instruments, as long as the company believes that their fair value can be reliably measured.

\section{Measurement: Levels of Fair Value}

In the U.S., companies generally use traditional valuation methods to estimate the enterprise value of the portfolio company issuing the securities. In September 2006, the FASB issued Statement No. 157, Fair Value Measurements (“SFAS 157”) (FASB 2006), which provides enhanced guidance on the use of fair value to measure assets and liabilities. SFAS 157 applies whenever other standards require (or allow) assets or liabilities to be measured at fair value, but it does not extend the use of fair value to any new circumstances. SFAS 157 is effective for fiscal years beginning after November 15, 2007 and is applied by companies operating in the private equity industry.

Under SFAS 157 (FASB 2006, para. 18), valuation techniques consistent with three possible approaches (the market approach, income approach, and/or cost approach) must be used to measure fair value. The Statement describes the "inputs" to valuation techniques (FASB 2006, paras. 21-31), a concept which refers broadly to the assumptions that market participants would use. Inputs may be observable or unobservable. Fair values are determined by reference to three types of inputs used to measure the asset. The level 1 and 2 categories look at observable market data, for instance quoted prices for identical assets for level 1, and other observable data such as quoted prices for similar assets for level 2. There is no observable market data for the level 3 category: the firm management must rely on its own assumptions and judgment.

\footnotetext{
${ }^{24}$ The full text of the act can be downloaded from the SEC website: www.sec.gov/about/laws/ica40.pdf.

${ }^{25}$ Cairns (2006) presents a thorough analysis of the current IAS/IFRS fair value guidance.
} 
At the international level, IAS 39 adds that "the fair value of investments in equity instruments that do not have a quoted market price in an active market ... is reliably measurable if (a) the variability in the range of reasonable fair value estimates is not significant for that instrument or (b) the probabilities of the various estimates within the range can be reasonably assessed and used in estimating fair value" (IASB 2003b, para. AG80). These excerpts from IAS 39 imply that investments in unlisted equity instruments can be reported at fair value if their fair value can be "reliably measured" (this is confirmed by our study of U.K. annual reports - see below). Companies can refer to IAS 39 (para. AG74) which states that "if the market for a financial instrument is not active, an entity establishes fair value by using a valuation technique. Valuation techniques include using recent arm's length market transactions between knowledgeable, willing parties, if available, reference to the current fair value of another instrument that is substantially the same, discounted cash flow analysis and option pricing models.” 


\section{APPENDIX 2}

\section{Preliminary information given to all participants}

You are an investor specialized in private equity investments. You have the opportunity to invest in 24 companies: your offer will be selected if you make the best proposal to the seller (call auctions). But be careful: if your price is too high, you will lose money! You have an initial available amount of $\$ 24,000$ in cash. Your goal is to maximize the value of your portfolio by the end of the game. The four best results on the market will receive a \$225 award each. For each round, you will have access to basic business and financial information on the targeted company. These data will help you in assessing the value of the company's shares (around \$1,000 each). This information is not comprehensive, but is critical to help you estimate the share price. You must first answer the following question:

Question 1: What is the price of this company's share?

Then, you must decide if you will bid to buy one share or not.

Question 2: Do you want to buy this share at this value? Yes/no

If you make an offer, it will be compared to your competitors' bids ${ }^{26}$ and you will receive one of the two following messages:

Message 1: Congratulations. Your offer was the highest, and has been accepted. One year later, the market value of this share turns out to be $\$ \mathrm{X} .{ }^{27}$ Therefore, you have made a gain (loss) of:

$$
\begin{aligned}
& \text { Market value (year t+1) \$X } \\
& \text { - Your offer (year t) - } \$ Y \\
& \text { = Gain (loss) } \quad \text { = } \$(X-Y)
\end{aligned}
$$

Message 2: Sorry, your offer is too low. Another investor won the call auction. You make 0 gain/loss for this round. Your offer was: \$Y. The winning offer was: \$Z.

As you can see, you will know the market value for year $\mathrm{t}+1$ AFTER participating in the call auction.

In both cases, you receive a summary of your current operation and all your past operations, with the current portfolio value (share value and available cash). You should then click on "next round" to continue the game.

\footnotetext{
${ }^{26}$ This sentence is included for the sake of increasing the realism of the experiment. The participants do not know that the "market" value is simulated by a model (see Appendix 4).

${ }^{27}$ This value corresponds to the price proposed by another investor one year later. We call this value "market" value in the paper.
} 


\section{APPENDIX 3 \\ Excerpts from the simulation}

\section{Panel A: Union Food}

\begin{tabular}{|c|c|c|c|}
\hline \multicolumn{4}{|c|}{ Audited financial information } \\
\hline Year ended (\$m) & 2005 & 2006 & Change \\
\hline Sales & 27.4 & 28.6 & $4 \%$ \\
\hline Profit/(loss) after tax & 1.2 & 1.3 & $8 \%$ \\
\hline Total assets & 34.3 & 34.7 & $1 \%$ \\
\hline \multicolumn{4}{|c|}{ Business environment } \\
\hline Overall risk assessment & \multicolumn{3}{|c|}{ Low } \\
\hline Business description & \multicolumn{3}{|c|}{ Manufacture of premium hand-made pastries } \\
\hline Salient fact & \multicolumn{3}{|c|}{ Was able to attract new investors in 2005} \\
\hline Dividends paid & \multicolumn{3}{|c|}{ Dividends in 2005 and 2006} \\
\hline \multicolumn{4}{|c|}{ Valuation of the projected investment } \\
\hline $\begin{array}{l}\text { Low valuation } \\
\text { Average valuation } \\
\text { High valuation }\end{array}$ & \multicolumn{3}{|l|}{995} \\
\hline Basis of valuation & \multicolumn{3}{|c|}{ Earnings multiple, Discounted cash flows } \\
\hline
\end{tabular}

\section{Panel B: Branlock Bakery}

\begin{tabular}{|c|c|c|c|}
\hline \multicolumn{4}{|c|}{ Audited financial information } \\
\hline Year ended (\$m) & 2005 & 2006 & Change \\
\hline Sales & 22.8 & 23.8 & $4 \%$ \\
\hline Profit/(loss) after tax & 1 & 1.1 & $10 \%$ \\
\hline Total assets & 28.6 & 28.9 & $1 \%$ \\
\hline \multicolumn{4}{|c|}{ Business environment } \\
\hline Overall risk assessment & \multirow{4}{*}{\multicolumn{3}{|c|}{$\begin{array}{l}\text { Low } \\
\text { Manufacture of premium hand-made pastries } \\
\text { Was able to attract new investors in } 2005 \\
\text { Dividends in } 2005 \text { and } 2006\end{array}$}} \\
\hline Business description & & & \\
\hline Salient fact & & & \\
\hline Dividends paid & & & \\
\hline \multicolumn{4}{|c|}{ Valuation of the projected investment } \\
\hline Low valuation & \multicolumn{3}{|l|}{939} \\
\hline Average valuation & \multicolumn{3}{|l|}{995} \\
\hline High valuation & \multicolumn{3}{|l|}{1052} \\
\hline Basis of valuation & \multicolumn{3}{|c|}{ Earnings multiple, Discounted cash flows } \\
\hline
\end{tabular}

Panel A is based on Limited disclosure, Gain, Low risk.

Panel B is based on Full disclosure, Gain, Low risk. 


\section{APPENDIX 4}

\section{Modeling the market (call auction)}

This appendix explains several factors relevant to understanding how the experiment was conducted.

\section{Construction of Scenarios}

The assessment supplied explicitly under “Overall risk assessment” (see Appendix 3) may be "high" or "low". This valuation is reinforced by the following implicit factors, which are introduced in different combinations according to the scenarios.

\section{Business Description}

There are 12 different descriptions, classified according to risk level as follows:

\begin{tabular}{|l|l|}
\hline \multicolumn{1}{|c|}{ Low risk } & \multicolumn{1}{|c|}{ High Risk } \\
\hline Manufacture of industrial doors and curtains & Remote telemetry data transmission systems \\
\hline Supply of powered access equipment for hire & $\begin{array}{l}\text { Computer software for ticketing and accounting } \\
\text { applications }\end{array}$ \\
\hline Provision of training and conference facilities & $\begin{array}{l}\text { Software developer for business management } \\
\text { applications }\end{array}$ \\
\hline Manufacture of premium hand-made French pastries & $\begin{array}{l}\text { Infrastructure installation for mobile telephone } \\
\text { operators }\end{array}$ \\
\hline Manufacture of air curtains and air handling equipment & Laboratory analysis service for clinical trials \\
\hline Hire of large crawler cranes to the construction industry & $\begin{array}{l}\text { Laboratory biological development of new genetic } \\
\text { therapy }\end{array}$ \\
\hline
\end{tabular}

\section{Salient facts}

\begin{tabular}{|l|l|}
\hline \multicolumn{1}{|c|}{ Low risk } & \multicolumn{1}{c|}{ High risk } \\
\hline Created before 2000 & Recapitalization in 2006 \\
\hline Was able to attract new investors in 2005 & Firm created in 2005 \\
\hline
\end{tabular}

\section{Income}

\begin{tabular}{|c|c|}
\hline Low risk & \multicolumn{1}{|c|}{ High risk } \\
\hline Dividends in 2005 and 2006 & Nil dividends \\
\hline
\end{tabular}

These combinations are constructed so that the Limited and Full disclosure scenarios can be compared directly, all other things being equal. This means that the same description (business description, salient facts and income) will occur twice, once for the Limited disclosure scenario and once for the Full disclosure scenario. To avoid memorization bias (favoring participants who memorized information rather than understood the contents), the firm name only is changed each time, and the financial data are approximately multiplied by a coefficient of 1.2. The two scenarios will be referred to as a pair (see an example in Appendix 3). 


\section{Method for Calculating Disclosed Fair Values and Low and High Valuations}

For each pair of scenarios, the following values are precalculated: values likely to be disclosed (Average valuation [i.e., fair value], Low valuation, High valuation) and market value (see later in this appendix). The calculation method depends on the domain (gain or loss) to which the pair of scenarios belong.

\section{Potential gain}

This will send a signal that there is a risk of undervaluing the project. There is therefore a high likelihood of the market value being higher than the disclosed value. This will be modeled by a random drawing from within the interval $[0.4 ; 0.5]$, whereas the actual value (market value) is drawn randomly from within the interval [0.45; 0.55]. This gives the following Average disclosed value:

Average disclosed value $=$ INVERSE GAUSSIAN DISTRIBUTION $(\mathrm{p}=0.45+$ hazard $( \pm 0.05)$, average $=1000$, $\mathrm{SD}=100$ if Scenario = low risk, 250 if Scenario = high risk)

The low and high published values are therefore calculated as follows:

Low (resp. High) valuation = INVERSE GAUSSIAN DISTRIBUTION $(p=0.45+$ hazard $( \pm 0.05)-($ resp. + ) 0.2 ; average $=1000 ; \mathrm{SD}=100$ if Scenario = low risk, 250 if Scenario = high risk)

This is therefore the value drawn from the same normal distribution as market value, but with lower (higher) probability in the interval [0.2;0.3] ([0.6;0.7]) for the low (high) valuation.

\section{Potential loss}

This will send a signal that there is a risk of overvaluing the project. There is therefore a high likelihood of the market value being lower than the disclosed value. This will be modeled by a random drawing from within the interval [0.5; 0.6$]$, whereas the actual value (market value) is drawn randomly from within the interval [0.45; 0.55]. This gives the following Average disclosed value:

Average disclosed value $=$ INVERSE GAUSSIAN DISTRIBUTION $(p=0.55+$ hazard $( \pm 0,05)$, average $=1000$, $\mathrm{SD}=100$ if Scenario = low risk, 250 if Scenario = high risk)

The low and high published values are therefore calculated as follows:

Low (resp. High) valuation = INVERSE GAUSSIAN DISTRIBUTION $(p=0.55+$ hazard $( \pm 0.05)-($ resp. + ) 0.2 , average $=1000, \mathrm{SD}=100$ if Scenario $=$ low risk, 250 if scenario $=$ high risk)

This is therefore the value drawn from the same normal distribution as market value, but with lower (higher) probability in the interval $[0.3 ; 0.4]([0.7 ; 0.8])$ for the low (high) valuation. 


\section{Winning Bid}

If the participant decides to participate in the auction, she must be informed whether she has won. The decision is determined using the following formula:

Winning bid = If (GAUSSIAN DISTRIBUTION (Bid price,1000; SD (100 ou 250)) > 0.4, "Yes"; "No")

In other words, if the participant's bid has an associated probability (calculated based on normal distribution with mean 1000 and standard deviation 100 or 250 [depending on the level of risk]) greater than 0.4 , then she will win the auction. ${ }^{28}$

\section{Method for Calculating Market Values}

For each pair of scenarios, all market values are based on $\$ 1,000$ adjusted by a random parameter (uniform law). The formula is as follows:

Market Value $=$ INVERSE GAUSSIAN DISTRIBUTION $(p=0.5+$ hazard $( \pm 0.05)$; average $=1000 ;$ SD $=100$ if Scenario = low risk, 250 if Scenario = high risk)

The market value is only revealed to the participant after the auction result is announced, whether or not she decides to participate.

\section{Example for Union Food (see Appendix 3)}

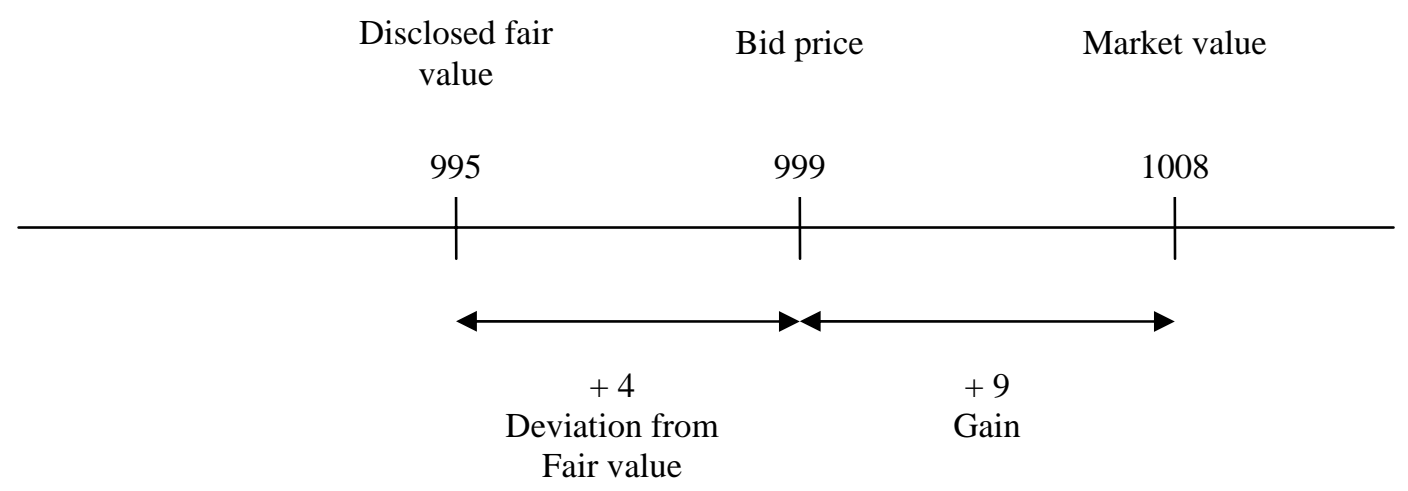

Example of computations:

Bid price: 999

Result of the market: Winning bid (highest offer).

Market value $=1,008$.

Gain $($ Loss $)=$ Market value - Bid price $=1,008-999=+9$ (gain) .

Return $=($ Gain $[$ Loss $]) /$ Bid price $=(1,008-999) / 999=9 / 999=0.9 \%$.

Disclosed fair value $(\mathrm{DFV})=995$ 
Deviation from Disclosed Fair Value $($ Deviation $)=($ Bid price - Disclosed fair value $) /$ Disclosed fair value $=(999-995) / 995=+0.40 \%$

${ }^{28}$ This procedure, although it has some common features with Becker-DeGroot-Marshak method (see Becker et al. 1964), differs from this method in which the price is determined by a random number generator. 


\section{REFERENCES}

Akerlof, G. A. 1970. The market for "Lemons": Quality uncertainty and the market mechanism. Quarterly Journal of Economics 84 (3): 488-500.

Ang, J. S., and T. Schwarz. 1985. Risk aversion and information structure: An experimental study of price variability in the securities markets. Journal of Finance 40 (3): 825-844.

Ashton, R. H., and S. S. Kramer. 1980. Students as surrogates in behavioral accounting research: Some evidence. Journal of Accounting Research 18 (1): 1-13.

Bailey, W., G. A. Karolyi, and C. Salva. 2006. The economic consequences of increased disclosure: Evidence from international cross-listings. Journal of Financial Economics 81 (1): 175-213.

Barlev, B., and J. R. Haddad. 2003. Fair value accounting and the management of the firm. Critical Perspectives on Accounting 14 (4): 383-415.

Barth, M. E. 1994. Fair value accounting: Evidence from investment securities and the market valuation of banks. The Accounting Review 69 (1): 1-25.

Barth, M. E., W. H. Beaver, and W. R. Landsman. 1996. Value-relevance of banks' fair value disclosures under SFAS No. 107. The Accounting Review 71 (4): 513-537.

Barth, M. E., and W. R. Landsman. 1995. Fundamental issues related to using fair value accounting for financial reporting. Accounting Horizons 9 (4): 97-107.

Becker, G. M., M. H. DeGrot, and J. Marschak. 1964. Measurig utility by a single-response sequential method. Behavioral Science 9: 226-232.

Benston, G. J. 2008. The shortcomings of fair-value accounting described in SFAS 157. Journal of Accounting and Public Policy 27 (2): 101-114.

Botosan, C. A. 2006. Disclosure and the cost of capital: What do we know? Accounting \& Business Research 36 (Special issue): 31-40.

Budescu, D. V., K. M. Kuhn, K. M. Kramer, and T. R. Johnson. 2002. Modeling certainty equivalents for imprecise gambles. Organizational Behavior \& Human Decision Processes 88 (2): 748-768.

Bushee, B. J., and C. Leuz. 2005. Economic consequences of SEC disclosure regulation: Evidence from the OTC bulletin board. Journal of Accounting \& Economics 39 (2): 233-264.

Cairns, D. 2006. The use of fair value in IFRS. Accounting in Europe 3 (1): 5-22.

Calegari, M., and N. L. Fargher. 1997. Evidence that prices do not fully reflect the implications of current earnings for future earnings: An experimental markets approach. Contemporary Accounting Research 14 (3): 397-433.

Camerer, C., and M. Weber. 1992. Recent developments in modeling preferences: Uncertainty and ambiguity. Journal of Risk \& Uncertainty 5 (4): 325-370.

Chen, Z., and L. Epstein. 2002. Ambiguity, risk and asset returns in continuous time. Econometrica 70 (4): 1403.

Chow, C. W., K. Haddad, and M. Hirst. 1996. An experimental market's investigation of discretionary financial disclosure. Abacus 32 (2): 133-152.

Curley, S. P., J. F. Yates, and R. A. Abrams. 1986. Psychological sources of ambiguity avoidance. Organizational Behavior \& Human Decision Processes 38 (2): 230.

Danbolt, J., and W. Rees. 2008. An experiment in fair value accounting: UK investment vehicles. European Accounting Review 17 (2): 271 - 303.

Diamond, D. W., and R. E. Verrecchia. 1991. Disclosure, liquidity and the cost of capital. Journal of Finance 46 (2): 1325-1359.

Du, N., and D. V. Budescu. 2005. The effects of imprecise probabilities and outcomes in evaluating investment options. Management Science 51 (12): 1791-1803. 
Eccher, E. A., K. Ramesh, and S. R. Thiagarajan. 1996. Fair value disclosures by bank holding companies. Journal of Accounting and Economics 22 (1-3): 79-117.

Einhorn, H. J., and R. M. Hogarth. 1985. Ambiguity and uncertainty in probabilistic inference. Psychological Review 92 (4): 433-461.

Einhorn, H. J., and R. M. Hogarth. 1986. Decision making under ambiguity. Journal of Business 59 (4): S225-S250.

Elliott, R. K., and P. D. Jacobson. 1994. Costs and benefits of business information disclosure. Accounting Horizons 8 (4): 80-96.

Elliott, W. B., F. D. Hodge, J. J. Kennedy, and M. Pronk. 2007. Are M.B.A. Students a good proxy for nonprofessional investors? The Accounting Review 82 (1): 139-168.

Ellsberg, D. 1961. Risk, ambiguity, and the savage axioms. Quarterly Journal of Economics 75 (4): 643-669.

FASB. 1980. Concepts statement No. 2: Qualitative characteristics of accounting information. Norwalk, CT: Financial Accounting Standards Board.

FASB. 1993. Statement of financial accounting standards (SFAS) No. 115 (amended): Accounting for certain investments in debt and equity securities. Norwalk, CT: Financial Accounting Standards Board.

FASB. 2006. Statement of financial accounting standards (SFAS) No. 157 (amended): Fair value measurements. Norwalk, CT: Financial Accounting Standards Board.

Foong, S.-Y., M. Lawrence, and M. O'Connor. 2003. The interaction of incentives and information disclosure: The case of confidence interval information. The British Accounting Review 35 (3): 233-255.

Gill, M. J., W. B. Swann, Jr., and D. H. Silvera. 1998. On the genesis of confidence. Journal of Personality and Social Psychology 75 (5): 1101-1114.

Godfrey, J., A. Hodgson, and S. Holmes. 2003. Accounting theory. 5th ed., Milton, Australia: Wiley.

Hall, C. C., L. Ariss, and A. Todorov. 2007. The illusion of knowledge: When more information reduces accuracy and increases confidence. Organizational Behavior and Human Decision Processes 103 (2): 277-290.

Heath, C., and A. Tversky. 1991. Preference and belief: Ambiguity and competence in choice under uncertainty. Journal of Risk and Uncertainty 4 (1): 5-28.

Highhouse, S. 1994. A verbal protocol analysis of choice under ambiguity. Journal of Economic Psychology 15 (4): 621-635.

Hirst, D. E., L. Koonce, and J. Miller. 1999. The joint effect of management's prior forecast accuracy and the form of its financial forecasts on investor judgment. Journal of Accounting Research 37: 101-124.

Hitz, J.-M. 2007. The decision usefulness of fair value accounting - a theoretical perspective. European Accounting Review 16 (2): 323-362.

Hodder, L., L. Koonce, and M. L. McAnally. 2001. SEC market risk disclosures: Implications for judgment and decision making. Accounting Horizons 15 (1): 49-70.

Hogarth, R. M., and H. Kunreuther. 1989. Risk, ambiguity, and insurance. Journal of Risk \& Uncertainty 2 (1): 5-35.

Hogarth, R. M., and S. Makridakis. 1981. The value of decision making in a complex environment: An experimental approach. Management Science 27 (1): 93-107.

Holm, C., and P. Rikhardsson. 2008. Experienced and novice investors: Does environmental information influence investment allocation decisions? European Accounting Review 17 (3): 537-557.

Huber, J., M. Kirchler, and M. Sutter. 2008. Is more information always better?: Experimental financial markets with cumulative information. Journal of Economic Behavior \& Organization 65 (1): 86-104. 
IASB. 2003a. International accounting standard (IAS) No. 32: Financial instruments: Disclosure and presentation (superseded). London, United Kingdom: International Accounting Standards Board.

IASB. 2003b. International accounting standard (IAS) No. 39: Financial instruments: Recognition and measurement. London: International Accounting Standards Board.

IASB. 2005. International financial reporting standard (IFRS) No. 7: Financial instruments: Disclosures. London, United Kingdom: International Accounting Standards Board.

IASB Expert Advisory Panel. 2008. Measuring and disclosing the fair value of financial instruments in markets that are no longer active. IASB.

IASC. 1989. Framework for the preparation and presentation of financial statements. London: International Accounting Standards Committee.

Johnson, E. J., and J. W. Payne. 1985. Effort and accuracy in choice. Management Science 31 (4): 395-414.

Kahneman, D., P. Slovic, and A. Tversky. 1982. Judgment under uncertainty: Heuristics and biases. New York: Cambridge University Press.

Kennedy, J., T. Mitchell, and S. E. Sefcik. 1998. Disclosure of contingent environmental liabilities: Some unintended consequences? Journal of Accounting Research 36 (2): 257-277.

King, R. R., and D. E. Wallin. 1995. Experimental tests of disclosure with an opponent. Journal of Accounting and Economics 19 (1): 139-167.

Landsman, W. R. 2007. Is fair value accounting information relevant and reliable? Evidence from capital market research. Accounting and Business Research 37 (3): 19.

Libby, R., R. Bloomfield, and M. W. Nelson. 2002. Experimental research in financial accounting. Accounting, Organizations and Society 27: 775-810.

Liyanarachchi, G., and M. Milne. 2005. Comparing the investment decisions of accounting practitioners and students: An empirical study on the adequacy of student surrogates. Accounting Forum 29 (2): 121-135.

Maines, L. A., and J. M. Wahlen. 2006. The nature of accounting information reliability: Inferences from archival and experimental research. Accounting Horizons 20 (4): 399425.

March, J. G. 1987. Ambiguity and accounting: The elusive link between information and decision making. Accounting, Organizations and Society 12 (2): 153-168.

Michaels, A. 2004. SEC mulls new disclosure rules. Financial Times (26 January): 18.

Miller, G. A. 1956. The magical number seven, plus or minus two: Some limits on our capacity for processing information. Psychological Review 63 (2): 81-97.

Mukerji, S., and J.-M. Tallon. 2001. Ambiguity aversion and incompleteness of financial markets. Review of Economic Studies 68 (237): 883-904.

Newell, A., and H. A. Simon. 1972. Human problem solving. Englewood Cliffs, NJ: Prentice Hall.

Nissim, D., and S. H. Penman. 2008. Principles for the application of fair value accounting. White Paper Number 2, Center for Excellence in Accounting \& Security Analysis Columbia Business School.

Park, M. S., T. Park, and B. T. Ro. 1999. Fair value disclosures for investment securities and bank equity: Evidence from SFAS No. 115. Journal of Accounting, Auditing \& Finance 14 (3): 347-370.

Plantin, G., H. Sapra, and H. S. Shin. 2008. Marking-to-market: Panacea or Pandora's box? Journal of Accounting Research 46 (2): 435-460.

Sarin, R. K., and M. Weber. 1993. Effects of ambiguity in market experiments. Management Science 39 (5): 602-615. 
Schick, A. G., L. A. Gordon, and S. Haka. 1990. Information overload: A temporal approach. Accounting, Organizations and Society 15 (3): 199-220.

Schroder, H. M., M. J. Driver, and S. Streufert. 1967. Human information processing. Rinehart: Winston Inc., Holt.

Thorngate, W. 1980. Efficient decision heuristics. Behavioral Science 25: 219-225.

Tversky, A., and D. Kahneman. 1982. Judgment under uncertainty: Heuristics and biases. In Judgment under uncertainty: Heuristics and biases, Eds, Kahneman, D., Slovic, P. and Tversky, A., Cambridge University Press, New York, 3-20. 
TABLE 1

Disclosure Practice of U.S. and U.K. Companies (Unlisted Equity Investments)

\begin{tabular}{|c|c|c|c|c|c|c|c|}
\hline & $\begin{array}{l}\text { GAAP } \\
\text { applied }\end{array}$ & $\begin{array}{l}\text { Valuation } \\
\text { at fair } \\
\text { value }\end{array}$ & $\begin{array}{l}\text { Reference } \\
\text { to the use } \\
\text { of } \\
\text { valuation } \\
\text { techniques }\end{array}$ & $\begin{array}{l}\text { Detail of the } \\
\text { cost and fair } \\
\text { value for each } \\
\text { investment (or } \\
\text { each of the } \\
\text { main } \\
\text { investments) }\end{array}$ & $\begin{array}{l}\text { Valuation } \\
\text { technique used } \\
\text { for each } \\
\text { investment (or } \\
\text { each of the } \\
\text { main } \\
\text { investments) }\end{array}$ & $\begin{array}{l}\text { Sensitivity } \\
\text { tests }\end{array}$ & $\begin{array}{l}\text { Range } \\
\text { of } \\
\text { values }\end{array}$ \\
\hline \multicolumn{8}{|l|}{ Panel A: USA } \\
\hline American Capital & U.S. & Yes & Yes & Yes & No & No & No \\
\hline Allied Capital & U.S. & Yes & Yes & Yes & No & No & No \\
\hline Ares Capital & U.S. & Yes & No & Yes & No & No & No \\
\hline MCG Capital & U.S. & Yes & Yes & Yes & No & No & No \\
\hline $\begin{array}{l}\text { PennantPark } \\
\text { Investment }\end{array}$ & U.S. & Yes & No & Yes & No & No & No \\
\hline $\begin{array}{l}\text { Hercules } \\
\text { Technology Growth } \\
\text { Cap }\end{array}$ & U.S. & Yes & Yes & Yes & No & No & No \\
\hline Kohlberg Capital & U.S. & Yes & No & Yes & No & No & No \\
\hline $\begin{array}{ll}\text { NGP } & \text { Capital } \\
\text { Resources } & \\
\end{array}$ & U.S. & Yes & Yes & Yes & No & No & No \\
\hline MVC Capital & U.S. & Yes & Yes & Yes & No & No & No \\
\hline $\begin{array}{ll}\text { Patriot } & \text { Capital } \\
\text { Funding } & \\
\end{array}$ & U.S. & Yes & Yes & Yes & No & No & No \\
\hline \multicolumn{8}{|l|}{$\begin{array}{l}\text { Panel B: United } \\
\text { Kingdom }\end{array}$} \\
\hline $\begin{array}{l}\text { Foreign \& Colonial } \\
\text { Investment Trust }\end{array}$ & U.K. & Yes & No & No & No & No & No \\
\hline $\begin{array}{l}\text { KKR Private Equity } \\
\text { Investors }\end{array}$ & U.S. & Yes & Yes & Yes & No & No & No \\
\hline SVG Capital & IFRS & Yes & Yes** & Yes & No & Yes & Yes \\
\hline European Capital & U.S. & Yes & Yes & Yes & No & No & No \\
\hline $\begin{array}{ll}\text { Electra } & \text { Private } \\
\text { Equity } & \\
\end{array}$ & IFRS & Yes & Yes** & Yes & Yes & No & No \\
\hline $\begin{array}{lr}\text { British Empire } & \text { End } \\
\text { Securities } & \text { and } \\
\text { General Trust } & \\
\end{array}$ & IFRS & Yes & Yes** & Yes & No & No & No \\
\hline British Assets Trust & U.K. & N/A* & N/A* & N/A* & N/A* & N/A* & N/A* \\
\hline $\begin{array}{l}\text { Pantheon } \\
\text { International } \\
\text { Participations } \\
\end{array}$ & U.K. & Yes & Yes & No & No & No & No \\
\hline JZ Equity Partners & U.K. & Yes & Yes** & Yes & Yes & No & No \\
\hline SVM Global Fund & U.K. & Yes & Yes** & Yes & No & No & No \\
\hline
\end{tabular}


TABLE 2

\section{Demographic Data}

\begin{tabular}{|c|c|c|c|c|c|c|}
\hline & $\mathrm{N}$ & mean & $\mathrm{sd}$ & $\min$ & p50 & $\max$ \\
\hline Age & 173 & 29.55 & 3.64 & 23 & 29 & 45 \\
\hline \multicolumn{7}{|l|}{ Background } \\
\hline - Business & 181 & $46 \%$ & $50 \%$ & $0 \%$ & $0 \%$ & $100 \%$ \\
\hline - Economics & 181 & $14 \%$ & $35 \%$ & $0 \%$ & $0 \%$ & $100 \%$ \\
\hline - Humanities & 181 & $6 \%$ & $24 \%$ & $0 \%$ & $0 \%$ & $100 \%$ \\
\hline - Science & 181 & $41 \%$ & $49 \%$ & $0 \%$ & $0 \%$ & $100 \%$ \\
\hline - Other & 181 & $4 \%$ & $21 \%$ & $0 \%$ & $0 \%$ & $100 \%$ \\
\hline \multicolumn{7}{|l|}{ Courses attended } \\
\hline - Accounting & 181 & $67 \%$ & $47 \%$ & $0 \%$ & $100 \%$ & $100 \%$ \\
\hline - Financial analysis & 181 & $43 \%$ & $50 \%$ & $0 \%$ & $0 \%$ & $100 \%$ \\
\hline - Corporate finance & 181 & $57 \%$ & $50 \%$ & $0 \%$ & $100 \%$ & $100 \%$ \\
\hline - Valuation & 181 & $23 \%$ & $42 \%$ & $0 \%$ & $0 \%$ & $100 \%$ \\
\hline \multicolumn{7}{|l|}{ Previously worked } \\
\hline - In accounting & 181 & $8 \%$ & $28 \%$ & $0 \%$ & $0 \%$ & $100 \%$ \\
\hline - In management control & 181 & $10 \%$ & $30 \%$ & $0 \%$ & $0 \%$ & $100 \%$ \\
\hline - In audit & 181 & $4 \%$ & $21 \%$ & $0 \%$ & $0 \%$ & $100 \%$ \\
\hline - In a bank & 181 & $13 \%$ & $34 \%$ & $0 \%$ & $0 \%$ & $100 \%$ \\
\hline - In an investment bank & 181 & $8 \%$ & $27 \%$ & $0 \%$ & $0 \%$ & $100 \%$ \\
\hline - Other & 181 & $64 \%$ & $48 \%$ & $0 \%$ & $100 \%$ & $100 \%$ \\
\hline
\end{tabular}




\section{TABLE 3}

\section{Market liquidity: Offer and Disclosure}

\begin{tabular}{|c|c|c|c|c|c|}
\hline $\begin{array}{l}\text { Panel A: Offer and Disclosure - Paired } \\
\text { Wilcoxon signed-rank test }\end{array}$ & $\begin{array}{l}\text { Number of } \\
\text { pairs }\end{array}$ & $\begin{array}{l}\text { Limited } \\
\text { disclosure }\end{array}$ & $\begin{array}{c}\text { Full } \\
\text { disclosure }\end{array}$ & z-Statistic & $\begin{array}{c}\text { Two- } \\
\text { Tailed } \\
\text { p-Value }\end{array}$ \\
\hline Paired Wilcoxon signed-rank test & $577^{\mathrm{a}}$ & 0.934 & 0.956 & -2.608 & 0.009 \\
\hline \multirow[t]{2}{*}{ Panel B: Mean (standard deviation) for Offer } & \multicolumn{2}{|c|}{ Low risk } & \multicolumn{2}{|c|}{ High risk } & \\
\hline & $\begin{array}{c}\text { Domain }= \\
\text { Loss }\end{array}$ & $\begin{array}{c}\text { Domain }= \\
\text { Gain }\end{array}$ & $\begin{array}{c}\text { Domain }= \\
\text { Loss }\end{array}$ & $\begin{array}{c}\text { Domain }= \\
\text { Gain }\end{array}$ & \\
\hline \multirow[t]{2}{*}{ Limited disclosure } & $\begin{array}{r}0.909 \\
(0.270)\end{array}$ & $\begin{array}{r}0.979 \\
(0.130)\end{array}$ & $\begin{array}{r}0.849 \\
(0.340)\end{array}$ & $\begin{array}{r}0.997 \\
(0.041)\end{array}$ & \\
\hline & $\mathrm{N}=141$ & $\mathrm{~N}=145$ & $\mathrm{~N}=142$ & $\mathrm{~N}=149$ & \\
\hline \multirow[t]{3}{*}{ Full disclosure } & 0.942 & 0.976 & 0.911 & 0.993 & \\
\hline & $(0.224)$ & $(0.148)$ & $(0.277)$ & $(0.082)$ & \\
\hline & $N=141$ & $\mathrm{~N}=145$ & $\mathrm{~N}=142$ & $\mathrm{~N}=149$ & \\
\hline \multirow[t]{3}{*}{$\begin{array}{l}\text { Panel C: Offer disclosure, domain and risk - } \\
\text { Repeated Anova - General results }\end{array}$} & $\begin{array}{l}\text { Number of } \\
\text { observations }\end{array}$ & & & & \\
\hline & $1154^{\mathrm{b}}$ & & & & \\
\hline & $\begin{array}{l}\text { Partial Sum } \\
\text { of Squares }\end{array}$ & df & $\begin{array}{l}\text { Mean } \\
\text { Square }\end{array}$ & F-Statistic & $\begin{array}{c}\text { Two- } \\
\text { Tailed } \\
\text { p-Value }\end{array}$ \\
\hline Disclosure & 0.141 & 1 & 0.141 & 4.303 & 0.038 \\
\hline Domain & 1.789 & 1 & 1.789 & 54.528 & 0.000 \\
\hline Risk & 0.105 & 1 & 0.105 & 3.213 & 0.073 \\
\hline Disclosure $\mathrm{x}$ Domain & 0.188 & 1 & 0.188 & 5.728 & 0.017 \\
\hline Disclosure x Risk & 0.015 & 1 & 0.015 & 0.469 & 0.494 \\
\hline Domain $\mathrm{x}$ Risk & 0.205 & 1 & 0.205 & 6.252 & 0.013 \\
\hline Disclosure x Domain x Risk & 0.015 & 1 & 0.015 & 0.463 & 0.497 \\
\hline Residual & 31.754 & 968 & 0.033 & & \\
\hline $\begin{array}{l}\text { Panel D: Offer, disclosure, domain and risk - } \\
\text { Simple effect tests - Analysis of variance }\end{array}$ & $\begin{array}{c}\text { Partial Sum } \\
\text { of Squares }\end{array}$ & $\mathrm{df}$ & $\begin{array}{l}\text { Mean } \\
\text { Square }\end{array}$ & F-Statistic & $\begin{array}{c}\text { Two- } \\
\text { Tailed } \\
\text { p-Value }\end{array}$ \\
\hline Low risk (Dom & 0.077 & 1 & 0.077 & 1.258 & 0.263 \\
\hline (Domain = Gain) & 0.001 & 1 & 0.001 & 0.044 & 0.833 \\
\hline High risk (Domain = Loss) & 0.275 & 1 & 0.275 & 2.854 & 0.092 \\
\hline High risk (Domain = Gain) & 0.001 & 1 & 0.001 & 0.200 & 0.655 \\
\hline
\end{tabular}

${ }^{\text {a }}$ Number of complete pairs.

${ }^{\mathrm{b}}$ Observations corresponding to the complete pairs $(577 * 2=1,154)$.

Presentation of the experiment and definition of the variables

Each of the 181 participants is asked to participate in 24 different auctions. Given a set of information, the participant has to assess the value of the firm and post her bid price. The participant is then asked if she wishes to participate in an auction for the share. We manipulate three variables: the information on fair value measurements (point estimate in Limited disclosure, versus point estimate plus a range of values in Full disclosure), the domain of the decisions (Gain versus Loss) and the business risk (Low versus High).

Offer measures the willingness to take part in the auction and is coded one when the participant decides to make an offer and zero otherwise. 


\section{TABLE 4}

\section{Reliability of accounting numbers: Deviation from Disclosed Fair Value and Disclosure}

\begin{tabular}{|c|c|c|c|c|c|}
\hline $\begin{array}{l}\text { Panel A: Deviation and Disclosure - Paired } \\
\text { Wilcoxon signed-rank test }\end{array}$ & $\begin{array}{l}\text { Number of } \\
\text { pairs }\end{array}$ & $\begin{array}{c}\text { Limited } \\
\text { disclosure }\end{array}$ & $\begin{array}{c}\text { Full } \\
\text { disclosure }\end{array}$ & z-Statistic & $\begin{array}{l}\text { Two- } \\
\text { Tailed p- } \\
\text { Value }\end{array}$ \\
\hline Paired Wilcoxon signed-rank test & $541^{\mathrm{a}}$ & -0.025 & -0.033 & 3.511 & 0.000 \\
\hline \multirow{2}{*}{$\begin{array}{l}\text { Panel B: Mean (standard deviation) for } \\
\text { Deviation }\end{array}$} & \multicolumn{2}{|c|}{ Low risk } & \multicolumn{2}{|c|}{ High risk } & \\
\hline & $\begin{array}{c}\text { Domain }= \\
\text { Loss }\end{array}$ & $\begin{array}{l}\text { Domain }= \\
\text { Gain }\end{array}$ & $\begin{array}{c}\text { Domain }= \\
\text { Loss }\end{array}$ & $\begin{array}{c}\text { Domain }= \\
\text { Gain }\end{array}$ & \\
\hline \multirow[t]{3}{*}{ Limited disclosure } & -0.038 & -0.005 & -0.068 & 0.001 & \\
\hline & $(0.038)$ & $(0.026)$ & $(0.051)$ & $(0.018)$ & \\
\hline & $\mathrm{N}=129$ & $\mathrm{~N}=142$ & $\mathrm{~N}=122$ & $\mathrm{~N}=148$ & \\
\hline \multirow[t]{3}{*}{ Full disclosure } & -0.036 & -0.014 & -0.091 & -0.002 & \\
\hline & $(0.030)$ & $(0.027)$ & $(0.056)$ & $(0.057)$ & \\
\hline & $\mathrm{N}=129$ & $\mathrm{~N}=142$ & $\mathrm{~N}=122$ & $\mathrm{~N}=148$ & \\
\hline \multirow[t]{3}{*}{$\begin{array}{l}\text { Panel C: Deviation disclosure, domain and } \\
\text { risk - Repeated Anova - General results }\end{array}$} & $\begin{array}{l}\text { Number of } \\
\text { observations }\end{array}$ & & & & \\
\hline & $1082^{b}$ & & & & \\
\hline & $\begin{array}{l}\text { Partial Sum of } \\
\text { Squares }\end{array}$ & df & $\begin{array}{l}\text { Mean } \\
\text { Square }\end{array}$ & F-Statistic & $\begin{array}{l}\text { Two- } \\
\text { Tailed p- } \\
\text { Value }\end{array}$ \\
\hline Disclosure & 0.019 & 1 & 0.019 & 13.161 & 0.000 \\
\hline Domain & 0.702 & 1 & 0.702 & 475.844 & 0.000 \\
\hline Risk & 0.069 & 1 & 0.069 & 47.009 & 0.000 \\
\hline Disclosure x Domain & 0.001 & 1 & 0.001 & 0.944 & 0.331 \\
\hline Disclosure x Risk & 0.006 & 1 & 0.006 & 4.250 & 0.040 \\
\hline Domain x Risk & 0.155 & 1 & 0.155 & 105.096 & 0.000 \\
\hline Disclosure x Domain x Risk & 0.016 & 1 & 0.016 & 10.985 & 0.001 \\
\hline Residual & 1.323 & 897 & 0.001 & . & . \\
\hline $\begin{array}{l}\text { Panel D: Deviation, disclosure, domain and } \\
\text { risk - Simple effect tests - Analysis of } \\
\text { variance }\end{array}$ & $\begin{array}{l}\text { Partial Sum of } \\
\text { Squares }\end{array}$ & $\mathrm{df}$ & $\begin{array}{l}\text { Mean } \\
\text { Square }\end{array}$ & F-Statistic & $\begin{array}{l}\text { Two- } \\
\text { Tailed p- } \\
\text { Value }\end{array}$ \\
\hline Low risk (Domain = Loss) & 0.000 & 1 & 0.000 & 0.183 & 0.669 \\
\hline Low risk (Domain = Gain) & 0.006 & 1 & 0.006 & 8.709 & 0.003 \\
\hline High risk (Domain = Loss) & 0.033 & 1 & 0.033 & 11.632 & 0.001 \\
\hline High risk (Domain = Gain) & 0.001 & 1 & 0.001 & 0.445 & 0.505 \\
\hline \multicolumn{6}{|c|}{$\begin{array}{l}\text { a Number of complete pairs when the participant made an offer. } \\
\text { b Observations corresponding to the complete pairs when the participant made an offer }(541 * 2=1,082) \text {. } \\
\text { Presentation of the experiment and definition of the variables }\end{array}$} \\
\hline \multicolumn{6}{|c|}{$\begin{array}{l}\text { Each of the } 181 \text { participants is asked to participate in } 24 \text { different auctions. Given a set of information, the } \\
\text { participant has to assess the value of the firm and post her bid price. The participant is then asked if she wishes to } \\
\text { participate in an auction for the share. We manipulate three variables: the information on fair value } \\
\text { measurements (point estimate in Limited disclosure, versus point estimate plus a range of values in Full } \\
\text { disclosure), the domain of the decisions (Gain versus Loss) and the business risk (Low versus High). } \\
\text { Deviation is the Deviation from Disclosed Fair Value (Deviation). It represents the difference between the bid } \\
\text { price proposed by the participant and the disclosed fair value of the asset as determined by valuation techniques, } \\
\text { scaled by this fair value to allow comparisons. }\end{array}$} \\
\hline
\end{tabular}


TABLE 5

Relevance: Return and Disclosure

\begin{tabular}{|c|c|c|c|c|c|}
\hline $\begin{array}{l}\text { Panel A: Return and Disclosure - Paired } \\
\text { Wilcoxon signed-rank test }\end{array}$ & $\begin{array}{l}\text { Number of } \\
\text { pairs }\end{array}$ & $\begin{array}{l}\text { Limited } \\
\text { disclosure }\end{array}$ & $\begin{array}{c}\text { Full } \\
\text { disclosure }\end{array}$ & z-Statistic & $\begin{array}{c}\text { Two- } \\
\text { Tailed } \\
\text { p-Value }\end{array}$ \\
\hline Paired Wilcoxon signed-rank test & $577^{\mathrm{a}}$ & 0.010 & 0.007 & 3.000 & 0.003 \\
\hline \multirow[t]{2}{*}{ Panel B: Mean (standard deviation) for Return } & \multicolumn{2}{|c|}{ Low risk } & \multicolumn{2}{|c|}{ High risk } & \\
\hline & $\begin{array}{l}\text { Domain }= \\
\text { Loss }\end{array}$ & $\begin{array}{l}\text { Domain }= \\
\text { Gain }\end{array}$ & $\begin{array}{l}\text { Domain }= \\
\text { Loss }\end{array}$ & $\begin{array}{l}\text { Domain }= \\
\text { Gain }\end{array}$ & \\
\hline \multirow[t]{3}{*}{ Limited disclosure } & 0.004 & 0.006 & 0.003 & 0.026 & \\
\hline & $(0.012)$ & $(0.017)$ & $(0.018)$ & $(0.018)$ & \\
\hline & $\mathrm{N}=141$ & $\mathrm{~N}=145$ & $\mathrm{~N}=142$ & $\mathrm{~N}=149$ & \\
\hline \multirow[t]{3}{*}{ Full disclosure } & 0.005 & 0.006 & 0.001 & 0.014 & \\
\hline & $(0.012)$ & $(0.010)$ & $(0.019)$ & $(0.033)$ & \\
\hline & $\mathrm{N}=141$ & $\mathrm{~N}=145$ & $\mathrm{~N}=142$ & $\mathrm{~N}=149$ & \\
\hline \multirow[t]{3}{*}{$\begin{array}{l}\text { Panel C: Return, disclosure, domain and risk - } \\
\text { Repeated Anova - General results }\end{array}$} & $\begin{array}{c}\text { Number of } \\
\text { observations }\end{array}$ & & & & \\
\hline & $1154^{b}$ & & & & \\
\hline & $\begin{array}{l}\text { Partial Sum } \\
\text { of Squares }\end{array}$ & $\mathrm{df}$ & $\begin{array}{l}\text { Mean } \\
\text { Square }\end{array}$ & F-Statistic & $\begin{array}{c}\text { Two- } \\
\text { Tailed } \\
\text { p-Value }\end{array}$ \\
\hline Disclosure & 0.002 & 1 & 0.002 & 7.696 & 0.006 \\
\hline Domain & 0.025 & 1 & 0.025 & 83.763 & 0.000 \\
\hline Risk & 0.008 & 1 & 0.008 & 25.933 & 0.000 \\
\hline Disclosure x Domain & 0.003 & 1 & 0.003 & 8.265 & 0.004 \\
\hline Disclosure x Risk & 0.004 & 1 & 0.004 & 14.071 & 0.000 \\
\hline Domain x Risk & 0.016 & 1 & 0.016 & 52.893 & 0.000 \\
\hline Disclosure x Domain x Risk & 0.001 & 1 & 0.001 & 4.702 & 0.030 \\
\hline Residual & 0.294 & 968 & 0.000 & . & 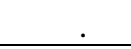 \\
\hline $\begin{array}{l}\text { Panel D: Return, disclosure, domain and risk - } \\
\text { Simple effect tests - Analysis of variance }\end{array}$ & $\begin{array}{l}\text { Partial Sum } \\
\text { of Squares }\end{array}$ & $\mathrm{df}$ & $\begin{array}{l}\text { Mean } \\
\text { Square }\end{array}$ & F-Statistic & $\begin{array}{c}\text { Two- } \\
\text { Tailed } \\
\text { p-Value }\end{array}$ \\
\hline Low risk $($ Domain $=$ Loss $)$ & 0.000 & 1 & 0.000 & 1.426 & 0.233 \\
\hline Low risk (Domain = Gain) & 0.000 & 1 & 0.000 & 0.027 & 0.869 \\
\hline High risk (Domain = Loss) & 0.000 & 1 & 0.000 & 0.472 & 0.493 \\
\hline High risk (Domain = Gain) & 0.011 & 1 & 0.011 & 15.273 & 0.000 \\
\hline
\end{tabular}

${ }^{\text {a }}$ Number of complete pairs.

${ }^{\mathrm{b}}$ Observations corresponding to the complete pairs $(577 * 2=1,154)$.

Presentation of the experiment and definition of the variables

Each of the 181 participants is asked to participate in 24 different auctions. Given a set of information, the participant has to assess the value of the firm and post her bid price. The participant is then asked if she wishes to participate in an auction for the share. We manipulate three variables: the information on fair value measurements (point estimate in Limited disclosure, versus point estimate plus a range of values in Full disclosure), the domain of the decisions (Gain versus Loss) and the business risk (Low versus High).

Return measures the return on investment for each round. If a participant decided to make an offer and if this offer was accepted, the Return is computed as the difference between the market value of the asset as simulated by our experimental model and the bid price proposed by the participant, scaled by this bid price to allow comparisons. If the participant decided not to make an offer or if her offer was rejected, Return is set to zero. 
FIGURE 1

Experimental design (for each round)

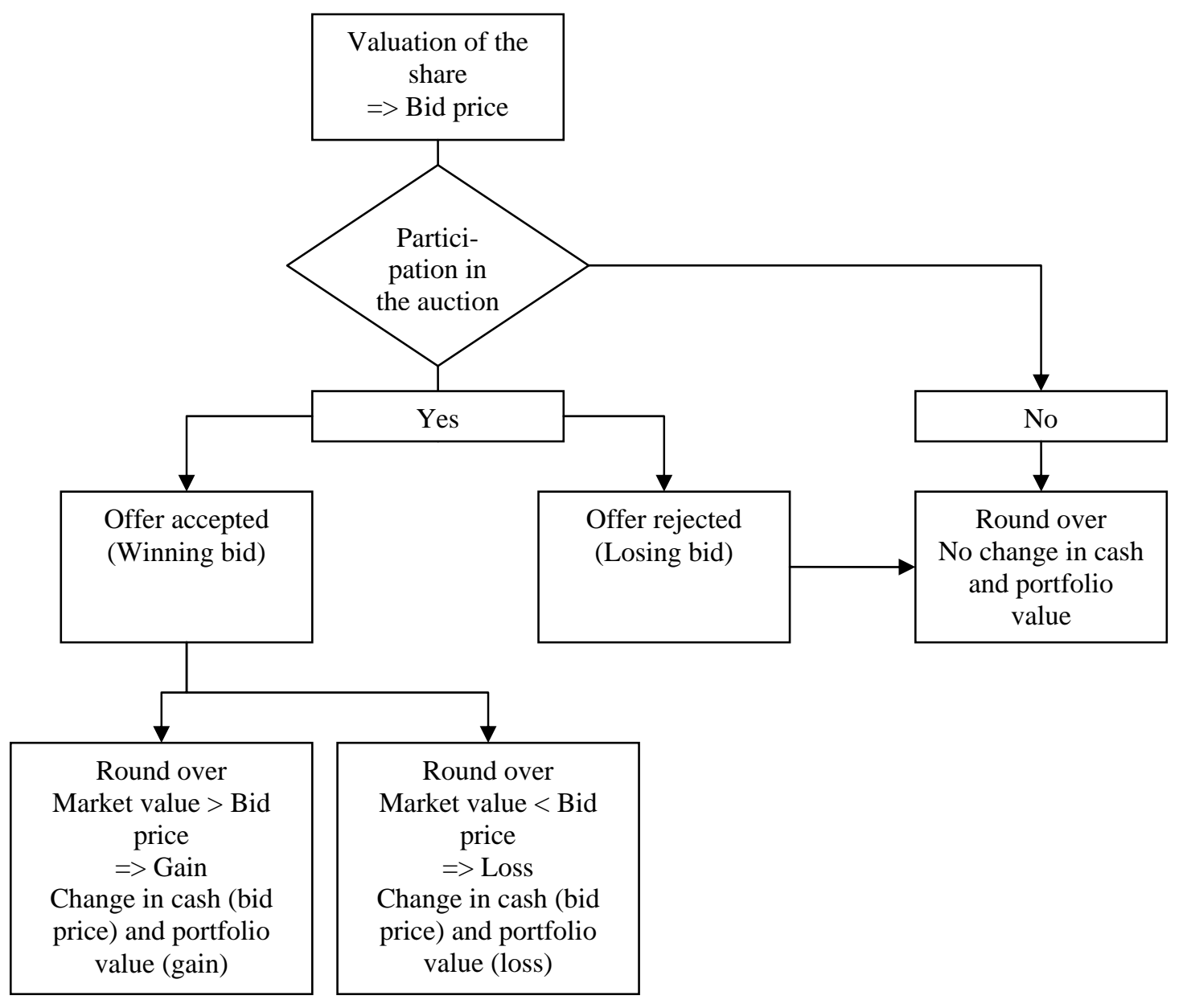

